\title{
PERSPECTIVES OF THE INTERNATIONAL MONETARY SYSTEM
}

\author{
Nenad Jankovic* \\ Faculty of Economics, University of Kragujevac, Kragujevac, The Republic of Serbia
}

During the 20th century, the dollar gained the status of the world's most important currency. Therefore, the Bretton Woods International Monetary System was based on the dollar. However, in the 1970s, the situation changed significantly - demand for dollars declined, the currencies of the most important European countries became convertible, the volume of international trade increased greatly, international capital flows were liberalized, the external convertibility of the dollar to gold was abolished, and the currencies began to fluctuate. In this way, the original Bretton Woods international monetary system ceased to exist. In addition to the changes, the functioning of the international monetary system is greatly impacted by the fact that the United States recorded an increasing amount of current account deficits from year to year and, in the 1980s, moved from the position of the net creditor to that of the net debtor, that the euro was created on the soil of the EU and that China became the world's largest exporter and one of the largest (if not the largest) world economies. For this reason, the theoretical assumptions of the international monetary system are systematized in the paper, the role of other world currencies is examined, and the question of why the dollar continues to be the dominant world currency is answered.

Keywords: Bretton Woods International Monetary System, dollar, euro, yuan, world currency

\section{JEL Classification: F31, F32, F33, F62, F65}

\section{INTRODUCTION}

The status of the world currency is not entirely defined by the relative size of the country and its presence in international markets. For this reason, although the United States surpassed Great Britain in size in the early phase of the $20^{\text {th }}$ century, at that time the dollar failed to take over the leading currency role

* Correspondence to: N. Jankovic, Faculty of Economics, University of Kragujevac, Dj. Pucara 3, 34000 Kragujevac, The Republic of Serbia; e-mail: njankovic@kg.ac.rs from the pound sterling; however, this happened later (Goldberg, 2011). The Bretton Woods International Monetary System emerged after the Second World War, when it became clear that the former, in some way, self-regulating version of the gold standard could not last. Insufficient reserves to guarantee the convertibility of the total paper money to gold have in the meantime conditioned the emergence of the gold-bar and gold-foreign exchange standard. At the same time, the events during and after the First and the Second World Wars contributed to the United 
States becoming a military, economic, financial and technological power, so it should not be surprising that the dollar nevertheless became the most important world currency of the 20th century. The following two facts were crucial: there was hunger for dollars and there was the convertibility of dollars to gold. Simply, the dollar became the world money the foreign exchange parity of other currencies was expressed in dollars, international payments were made in dollars, prices were invoiced in dollars, monetary reserves were kept in dollars, the savings were kept in dollars and the gold exchange system became the gold and dollar system.

However, already in the early 1970s, a lot changed - the currencies of the most important European countries became convertible, the volume of international trade increased multiple times, international capital flows were liberalized, the foreign convertibility of the dollar to gold was abolished, currencies started fluctuating - in a way, the original Bretton Woods International Monetary System ceased to exist. Nevertheless, in addition to all of these changed circumstances and the fact that the United States record an enormous foreign trade and budget deficit from year to year, the dollar continues to enjoy general confidence in the world and is accepted as a means of payment, account, and reserves. Thus, in the $21^{\text {st }}$ century, the dollar remains (for now) the most important world currency. The question arises as to how this is possible when no one likes the dollar standard. Although many years have passed since the abandonment of the original Bretton Woods International Monetary System, no other has been officially established. It is considered necessary that certain reforms should be made - to create an international monetary system that will reduce the impact of the dollar and take into account all of the new changes in international economic relations. According to R. Triffin (1978), when it comes to the international monetary reform, there are two main approaches - a monetary reform at the world level and a regional monetary cooperation or integration. For now, the creation of some kind of world money seems unlikely - it is not known who would create it, nor is it known who would control it. Simply, there is no consensus at the global level. On the other hand, there are thoughts on the creation of a kind of multi- currency international monetary system, where, owing to their position in the international economic order, the euro and the Chinese yuan should take their positions.

The aim of this paper is to clarify the theoretical assumptions about the existence of the Bretton Woods International Monetary System and to also point out the significance of the changes that have occurred in the meantime.

According to the abovementioned aim of the research, the following hypothesis can be singled out as crucial:

$\mathrm{H}$ : Despite the facts that there was the abolition of the foreign convertibility of the dollar to gold, that the euro was created as the common currency of the eurozone, and that China became the world's largest exporter, the dollar remains the most important world currency.

The qualitative methodology based on the study and descriptive analysis of the research problem will be used in the paper. The research study will examine the relevant foreign and domestic literature based on the theoretical generalizations and experiences of the authors who have dealt with the subject matter. Starting from the relevant literature, whether, in addition to all of the changed circumstances in the international monetary system, the dollar remains dominant, i.e. what is needed in order for other currencies (primarily the euro and the yuan) to create a multi-currency international monetary system, will be analyzed.

The rest of the paper is organized as follows: the most important characteristics of the original Bretton Woods International Monetary System will be discussed in the second part of the paper; the third part deals with the causes and consequences of the imbalance in the current accounts of certain countries; the fourth and the fifth parts examine the potential of the euro and the yuan as international currencies, while the sixth part is dedicated to the impact of globalization on the international monetary system. The drawn conclusions are presented in the seventh part. 


\section{THE ORIGINAL BRETTON WOODS INTERNATIONAL MONETARY SYSTEM}

Classical economists argue that money has its three functions - it serves as a means of exchange, as a unit of account, and as a value guard. The role of international money is the same - it is used for settling international payments, fixing prices and is kept as liquid assets for international transactions. An additional dimension is provided by the difference in the behavior of the private sector and central banks. Based on the abovementioned, the dollar, as the most important international currency, can be said to perform six functions. The dollar as a means of exchange in the private sector represents the intermediary between the currencies, while with the purchase and sales by the central banks it represents the currency used for an intervention in the market. Trade agreements denominated in dollars represent the dollar as the invoice currency (in the private sector), while the central bank uses it to express a local currency in dollars (pegged it to the dollar - exchange rate). Finally, if viewed as a value guard, private individuals keep liquid assets denominated in dollars (some sort of a banking role), while central banks keep the dollar as a reserve currency (Krugman, 1984).

As long as there was a complete exchange of the dollar to gold, central banks accumulated dollar assets and the Bretton Woods Monetary System operated smoothly. Confidence in the US willingness to convert dollars to gold influenced an increase in the share of the dollar in foreign-exchange reserves. However, at the beginning of the 1960s, the problem of long-term confidence in the sustainability of such a system appeared. Due to an increase in the world central banks' dollar assets, the amount of dollar reserves surpassed the US gold reserves, which prevented the American Central Bank (FED) from repurchasing all of the dollars (if foreign central banks wanted to replace all of their dollar reserves with gold) (Kovačević, 2015). In this manner, the United States was forced to abolish the foreign convertibility of the dollar to gold, thus destroying one of the pillars of the original Bretton Woods International Monetary system. In the following period, it was a system that was increasingly gaining in trust - it was necessary to believe in the stability of the dollar. As soon as there would be a disturbance, a crisis of confidence, such a system would no longer work properly. On the other hand, the significant use of the dollar is exactly what led to this instability of the system. The growing need for international liquidity was satisfied with an increasing amount of dollars, which remained outside the US, which, on the other hand, increased the US balance of payments problem. The cumulation of the US balance of payments deficit and the increase in foreigners' dollar receivables have led to reduced confidence in the dollar. Such a situation can be said to be one of the significant disadvantages of this established international monetary system (a "factory error", as some authors point out) - the currency of a country with a large (and increasing) deficit should enjoy general trust in the world and be accepted there as a means of payment, accounting, and reserves (Jovanović Gavrilović, 2012).

At that point, the question arose as to the position of the dollar after the end of dollar to gold convertibility, i.e. whether the dollar would remain to be the generally accepted currency and whether the US would continue to be able to finance the current account deficit without cover. However, the US used its influence over the OPEC countries (primarily Saudi Arabia) and committed them to sell oil exclusively in dollars. Instead of gold, oil ("black gold"), as the driver of the world economy and trade, has become the backbone of the modified international monetary system. Given the fact that there was no fixed link between oil and the dollar, the United States was allowed to lead a more loose fiscal policy, and due to the so-called Petrodollar standard, the dollar remained the most important world reserve currency (Filipović i Garić, 2014).

Some economists believe that a lack of the diversification of reserve currencies is the weakness and vulnerability of such an international monetary system, as this can lead to a lack of liquidity, excessive privileges, erroneous capital flows and the encouragement of a weak fiscal discipline in the countries whose currency is used as the reserve. However, according to others, the dominance of several currencies is good and the dominant 
currencies provide high-quality and safe assets during a financial crisis. Nevertheless, regardless of these opposing attitudes, the global economy is becoming increasingly multipolar. Significant structural changes have supported this transformation - including the rapid expansion and the increased connection of the global economy and financial markets. In this context, the key question is whether the transformation of the global economy will result in a more diversified reserve currency system (Tovar \& Nor, 2018)?

The conclusion is that there is a great paradox about the use of the dollar. Although no one likes the dollar standard, the dollar continues to be used. The country that fixes its exchange rate against the dollar will tend to intervene in the foreign exchange market in dollars and accumulate reserves in dollars. This country will choose the dollar for commercial and financial transactions, thus limiting the risk of a foreign exchange rate (Farhi, Gournchas \& Rey, 2011). Despite the turbulence in markets around the world and significant fluctuations in the value of the dollar in the past period, the importance of the dollar has not significantly decreased (neither if used as a currency linked to the value of the domestic currency nor as an international reserve currency) (Goldberg, 2010). For this reason, the established procedures of clearing and the mechanism of international payments help the dollar to retain the position it gained in international trade. As the main monetary mechanism, it ensures that international trade remains in some way multilateral, rather than narrowly bilateral. Simply put, this system is still too valuable to be lost and too difficult to be replaced (McKinnon, 2013).

\section{THE CAUSES AND CONSEQUENCES OF A LARGE IMBALANCE IN THE CURRENT ACCOUNTS OF CERTAIN COUNTRIES}

The imbalance in the current account of certain countries is one of the key macroeconomic imbalances that significantly influenced the emergence of the last financial crisis. In most cases, the imbalance is concentrated in a small group of regions or countries, but the right picture is obtained if we look at the countries concerned. Due to the size of its own economy, the US and the US current account deficit can pose a major problem for the sustainability of the existing system. There is no clearly defined limit of the sustainability of the current account deficit. Simply, someone's deficit will be sustainable as long as creditors have confidence in debtors. However, some economists believe that a current account deficit greater than $5 \%$ of the GDP is a problem. In 2006, the US current account deficit exceeded that limit and reached nearly $6 \%$ of the US GDP. At that time, the deficit accounted for about $75 \%$ of the current account surpluses of Germany, Japan, China and all of the world's other surplus countries (Obstfeld \& Rogoff, 2005). By definition, a current account deficit (surplus) is equal to negative (positive) net savings. In this way, the global imbalance can be seen as the continuing financing of the US consumption by the net savings of the surplus countries.

The global imbalance has allowed global aggregate demand to keep pace with the rapid expansion of the global aggregate supply (primarily) due to the integration of China and India into the world economy (Adams \& Park, 2009). In those years, the two most important things that affected the large US current account deficit were the increase in the US demand for foreign goods and the increase in foreign demand for US assets (Blanchard, Giavazzi \& Sa, 2005). Many economists regard this kind of global inequality as unsustainable. It is considered that, if foreigners (governments and the private sector) cease to buy dollar assets for some reason, this may trigger a significant decline in the value of the dollar in foreign exchange markets and jeopardize the ability of the US to borrow from abroad. At the same time, although foreign central banks keep almost one-half of the outstanding US Treasury securities, the United States is one of the few countries that can borrow even more, because it borrows in its own currency and because it is immune to the usual risk faced by other debtor countries, whose debts are in a foreign currency. In addition, there is a possibility that the FED will print enough money to repay the debt (McKinnon, 2013).

Surprisingly, despite some political and economic disagreements with the United States, it can be 
concluded that China has become more or less inadvertently the pillar of this established dollar standard. This assertion is reflected in the following (McKinnon, 2013):

- The snowball effect: The great expansion of Chinese trade with other emerging markets and countries producing primary products throughout the world, where the dollar is both the invoice currency for goods and the clearing currency for making international payments. This reduces transaction costs and increases the liquidity of dollar-based markets.

- The macro-stabilization effect: Since 1994, China has succeeded in following a countercyclical fiscal (credit) policy so as to stabilize its own GDP growth at a higher level, which somewhat buffers the cyclical instability emanating from the United States.

- The finance effect: China provides finance for the large US fiscal deficit. If, following China, foreigners collectively ceased to buy Treasury bonds and other dollar assets, a credit crisis in the United States would ensue.

There is no unanimous opinion about the impact of China on the world economy. While some economists believe that China has already become the leading economic power, there are those who consider it is necessary for many years to pass so that, realistically speaking, the Chinese influence could be greater than (above all) the American. Certainly, China has become the largest creditor of the United States, and the following figures support the fact that in the $21^{\text {st }}$ century, viewed through the relationship between the two countries, much has changed in terms of the redistribution of economic power in the world.

Figure 1 displays the movement of the GDP in the two countries between the years 2000 and 2017, measured in the current prices, according to the purchasing power parity. Although at the beginning of the observed period China's GDP was 2.7 times smaller than that of the US, in only 15 years China's GDP became larger, and in 2017, according to the IMF's estimates, this difference was almost 4,000 billion dollars. In the observed period, China's GDP grew 6.25 times, whereas America's GDP only grew 1.88 times. The only indicator that the US is still far ahead of China is the GDP per capita (also the current prices, according to the purchasing power parity) - Figure 2. According to the International Monetary Fund's (IMF) estimates in 2017, the GDP per capita in the United States was 59,495.34 dollars, and 16,624.41 dollars in China. Nevertheless, there

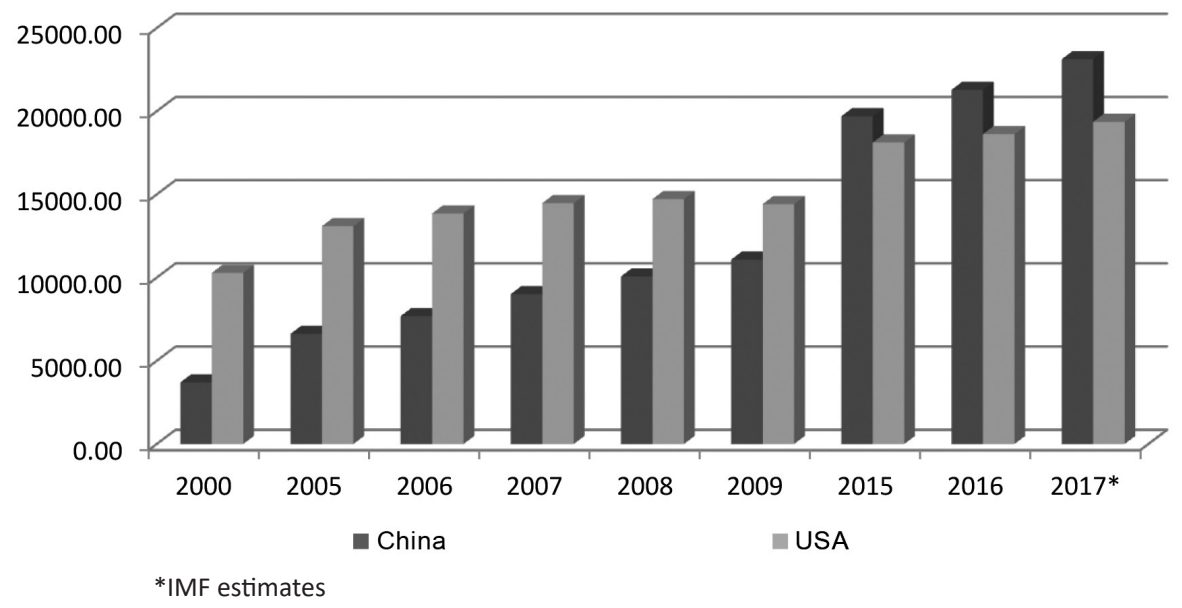

Figure 1 The GDP, the current prices, the PPP, in billions of dollars 
is also a significant difference here when comparing the increase at the beginning of the observed period. The GDP per capita in China increased 5.7 times and in the United States there was only an increase of 1.63 times; so, the conclusion is that this difference is decreasing. Based on the above data, it is noticeable that the financial crisis had significant consequences for the US economy - there was a decline in these indicators in certain years in the United States, while China has been experiencing constant growth. Figure 3 best illustrates the aforementioned redistribution of economic power. The share of these two economies in the global GDP increased (according to the IMF's estimates) in the observed period by over $5 \%$ and amounted to around $33.55 \%$. However, this increase occurred as a result of a reduced share of the US GDP by more than 5\% (from $20.62 \%$ to $15.29 \%$ ) and a significant increase in the share of China's GDP of almost $11 \%$ (from $7.42 \%$ to $18.26 \%$ ). In addition to the significantly high share of China's GDP, based on the above data, it can be concluded that there has been an increase in the concentration of economic power, so that the EU GDP, together with that of these two countries, represents about $50 \%$ of the world's GDP.

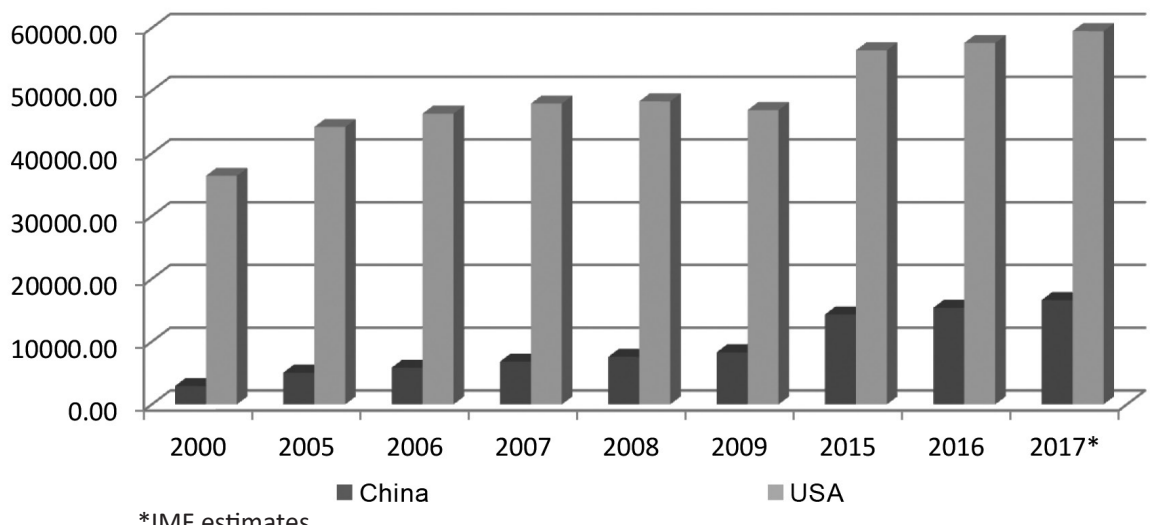

Figure 2 The GDP per capita, the current prices, the PPP, in dollars

Source: International Monetary Fund, 2017

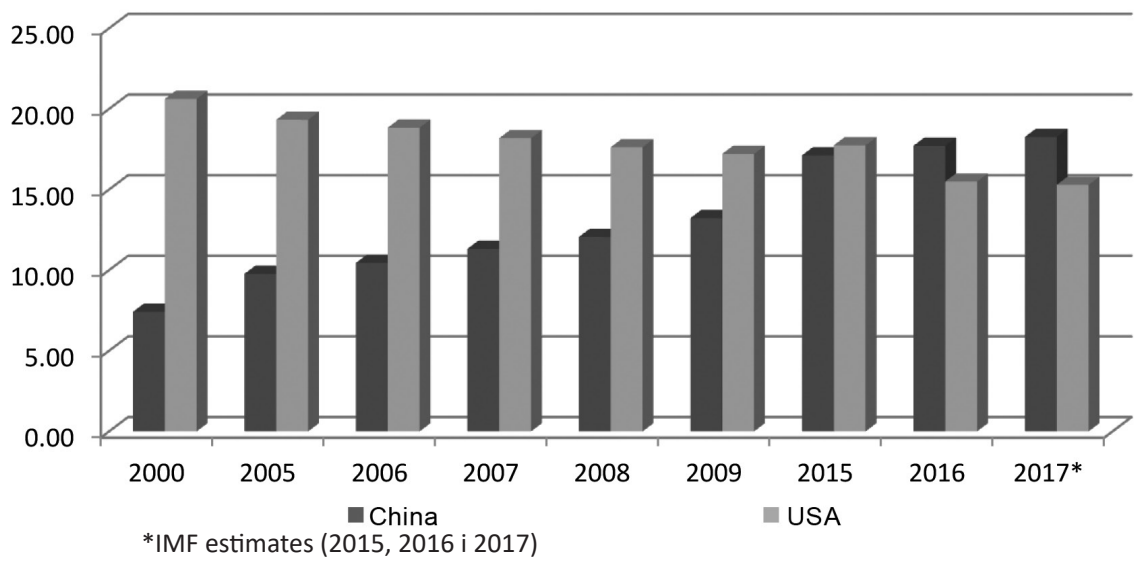

Figure 3 The GDP (PPP), the share in the world GDP 
The following Figures 4, 5, 6 and 7 show why the abovementioned large imbalance in the current accounts of certain countries exists. Theoretically, in the long run, one country should spend as much as it produces, and invest as much as it saves. However, in practice, this is usually not the case, and therefore there are deficit countries and surplus countries. Due to the size of their economies, the US and China are very important representatives of these groups. In the observed period, investments in China amounted to an average of $42.19 \%$ of the GDP, whereas in the United States they amounted to only $21.83 \%$ of the GDP. At the same time, in China, savings accounted for the GDP at an average of $47.23 \%$, unlike those in the US, where this share was $17.05 \%$. The asymmetric position of these two superpowers is obvious - China has a significant surplus for foreign investments (it invests most of it in the US Treasury securities), whereas the US investment activity largely depends on someone else's money. China invests most in the

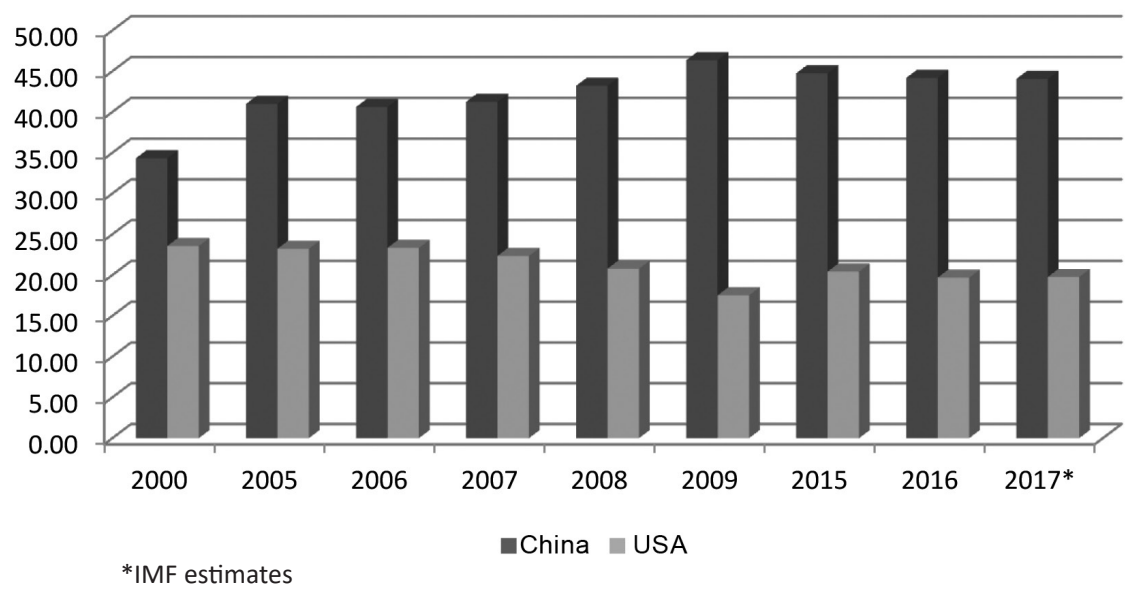

Figure 4 The total investments, in \% of the GDP

Source: International Monetary Fund, 2017

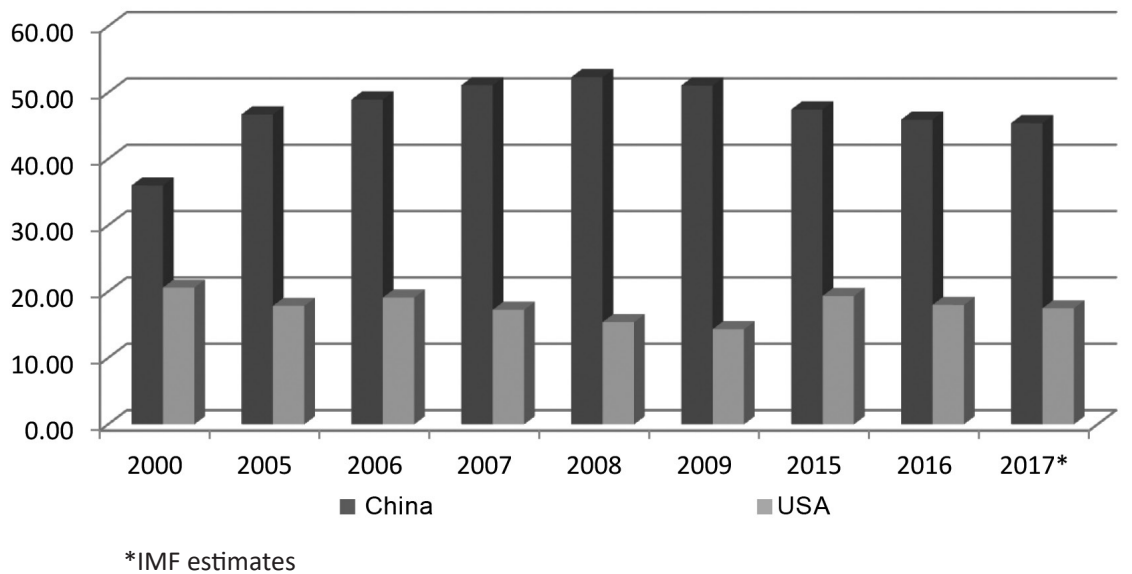

Figure 5 Gross national savings, in \% of the GDP

Source: International Monetary Fund, 2017 
US financial market due to the dollar status and the fact that it is the most developed market in the world. This raises the liquidity of the market and reduces the level of the interest rate in the market. However, in this way, the consumption of the US economy is generated, which is largely compensated for by import from China. On the other hand, China increases demand for the dollar and leads to the appreciation of the dollar against the yuan, which makes the yuan even more underestimated, and China's exports to the US market even more competitive. Precisely this (un)proven underestimation of the yuan is one of the key points of the dispute between these two countries (Filipović i Garić, 2014).

The public debt of both countries has increased it could be said to have doubled compared to the beginning of the observed period. However, the starting points were different - in 2001, the total public debt in China amounted to $24.38 \%$ of the GDP, and the IMF's estimates for 2017 amounted to $47.61 \%$ of the GDP. In the United States, the public debt amounted to $53.022 \%$ of the GDP in 2001, and as of 2012 , it was over $100 \%$ of the GDP, and the estimates for 2017 amounted to 108.14\% of the GDP (China has a significant share in this debt, of course). Thus, the above-stated fact that China is currently one of the world's largest investors and creditors of the US is confirmed. On the other hand, in the observed period, the United States constantly consumed more than they produced, which is reflected in the current account deficit (Figure 6) and the net international investment position (Figure 7). Although the current account deficit after the global financial and economic crisis was reduced and amounted to about $2.5 \%$ of the GDP, in 2005 and 2006, the deficit was over $5 \%$ of the GDP, so the question of its sustainability could be raised. In particular so when we look at the absolute amount of the deficit - in those years, it was about 800 billion dollars. The data are even more important when the net international investment position of the US is included in the analysis. The US switched from the position of the international net creditor (in 1980, the net international investment position amounted to a maximum of 296.8 billion dollars) to the position of the international net debtor in 1989 (33.7 billion dollars). Since then, the US debt was rising steadily to reach a maximum of 8,318.4 billion dollars in 2016 . Given the size of the US economy, the good thing is that, in relative terms, it is still not such a large amount (about $45 \%$ of the US GDP).

\section{THE POTENTIAL OF THE EURO}

The common European currency (the euro), introduced by 11 countries (currently 19), has been

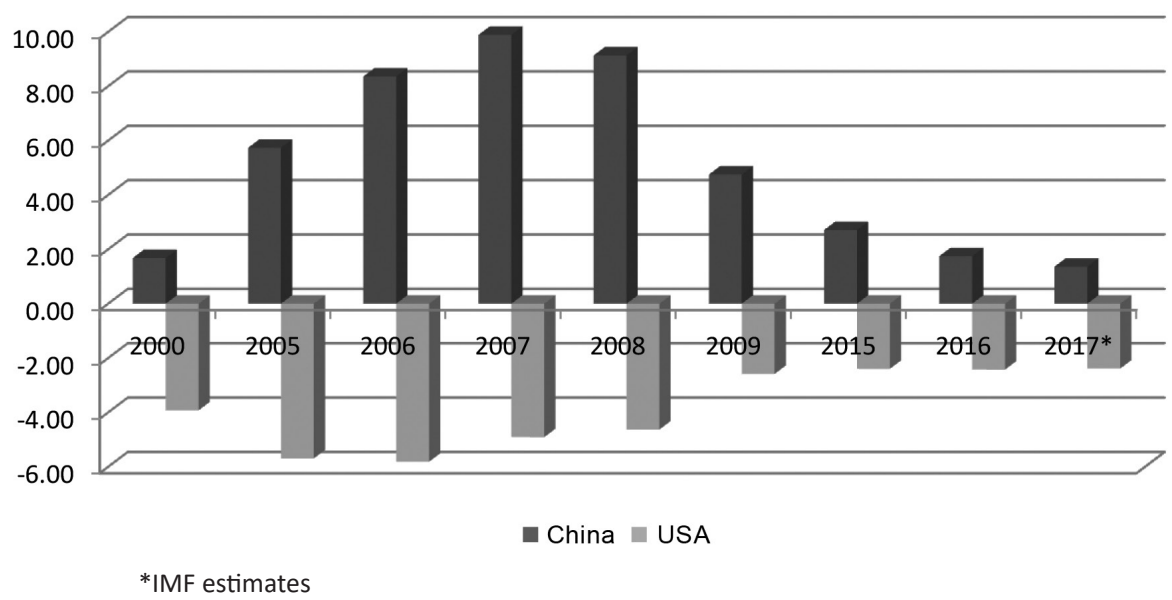

Figure 6 The current account balance, in \% of the GDP 


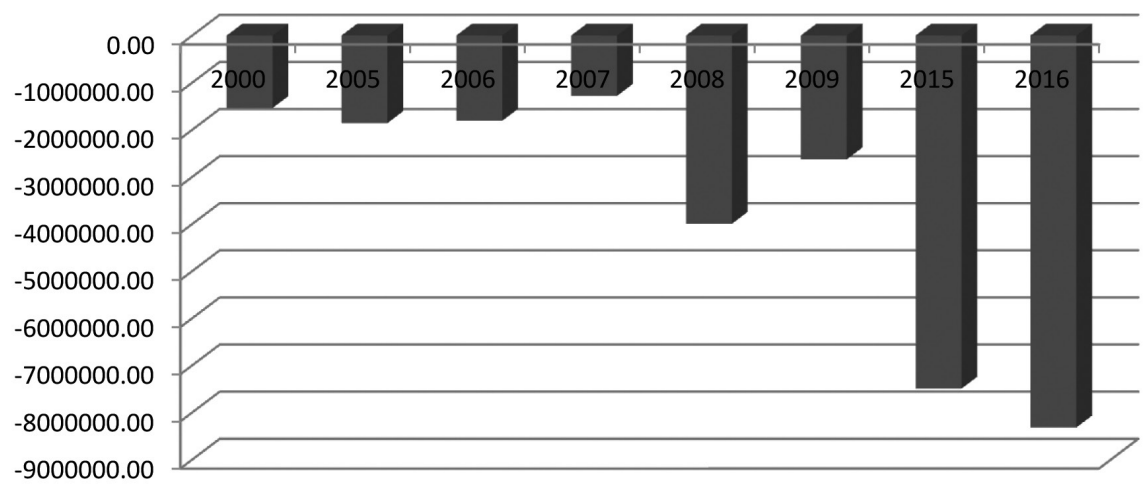

Figure 7 The net international investment position of the US, in millions of dollars

Source: Bureau of Economic Analysis, 2018

seen by its creators (and the wider economic public) as the currency that should stop and reduce the dollar's dominance as a world currency. The euro has taken its position in the international market and is the most important currency after the dollar. However, after all these crisis years, it has become obvious that the euro had been introduced before all the necessary conditions were met. During the introduction of the euro, its creators were probably aware of the fact that this was incomplete and a semi-solution. Namely, the greater economic and political integration of the eurozone countries should take place or its breakdown will occur. The introduction of the euro should not be the goal, but a means to achieve greater goals. It was considered that the introduction of the common currency would accelerate economic integration and prepare a favorable ground for deeper political integration; however, instead of that, there were opposite effects - the growth rates were not at a satisfactory level, the divisions still remain. If the GDP per capita is taken as one of the basic indicators of the economic progress of a country (or, in this case, of a group of countries), when it comes to the eurozone, the data are devastating - between 2007 and 2015, the decline in the real GDP per capita of $1.8 \%$ was recorded in the eurozone (simultaneously, there was an increase in the US by more than 3\%, although the global financial and economic crisis emerged in the USA) (Štiglic, 2016). In addition, although the new Member
States recorded higher growth rates than the old member countries, a low starting point was the major problem; therefore, there is still the division between "the core" and "the periphery", "the west" and "the east", and "the north" and "the south". In addition to economic inequalities and the problems created by such a situation, there are disagreements on the other, very important issues that make the functioning of the EU, and especially the EMU, more difficult. Currently (the beginning of 2018), great pressure can be said to be created by the problems concerning the independence of Catalonia, the withdrawal of Great Britain from the EU, and the influx of migrants. The Great World Financial Crisis revealed certain weaknesses of the EMU, and for several years after that, the euro was losing its significance as a world currency. Only in 2016 was the recovery recorded and did the euro record an increase in the share in the total world foreign exchange reserves (according to the constant foreign exchange rate, after 6 years of reduction in the share (from 22.3\% in 2009), in 2016 an increase (19.7\%) was recorded compared to 2015 (19.4\%) and global payments (from $29.4 \%$ of the share in 2015 to $31.3 \%$ in 2016) (ECB, 2017).

In order for the euro to continue to strengthen its role in the international monetary system, it is necessary to overcome the problems of the state debts of the peripheral member states, carry out 
reforms, primarily in the fiscal field, and create sufficiently reliable assets (the euro bond) that will be able to match the depth of the US financial market. Investors continue to have great confidence in the US government bonds and because of their high liquidity and security they practically identify them with money, as the most liquid asset (Kovačević, 2011). Because of all of the abovementioned, Dž. Štiglic believes that, in order for the eurozone to survive, and later even further jeopardize the position of the dollar, it is necessary to carry out the structural reforms of the eurozone itself: to establish a banking union, consolidate the debt, create a common framework for stability, lead the right convergence policy that will lead to structural realignment, promote full employment and growth for the whole of Europe and have full commitment to common prosperity. The agreement on the banking union has been reached in addition to joint supervision, it is necessary to have joint deposit insurance and joint problem solving (the same procedures for banks that cannot fulfill their obligations).

However, it is essential that a common regulatory system be set up in the right way - not to act as an automatic destabilizer, but to, with certain (greater) authorities and adequate instruments, stimulate expansion (limit lending) where necessary. Debt consolidation should also be approached cautiously. Any form of successful economic integration certainly implies some sort of assistance that stronger countries provide to the weaker (stronger member states must be aware of that).

In doing so, it is extremely important to properly use this consolidated debt - limit it if necessary, spend it on investment exclusively in certain parts of the economy (e.g. the infrastructure and education), and for any over-indebtedness to comply with the prescribed procedure. The fulfillment of the Maastricht criteria have proved insufficient to maintain the stability of the eurozone as a whole, so that the common framework for stability implies action in the following directions: the fundamental reform of the Maastricht convergence criteria (primarily through the creation of a common fiscal framework), a collective action for solving the basic problems through the Stabilization
Solidarity Fund, commitment to progressive automatic stabilizers, increasing the flexibility of the monetary policy, the introduction of regulations to control market-generated instabilities, and leading a stabilizing fiscal policy.

The real convergence policy involves the adoption of certain measures that will discourage countries from maintaining a surplus of current accounts. Achieving the current account balance for the region as a whole is not good enough. Individually, this can mean that there are countries with both a surplus and a deficit, which can lead to problems in time (primarily with respect to the financing of the deficit) so that the goal should be to prevent excessive imbalances within the eurozone. Full employment and continuing growth are the major problem for the eurozone. Change in the ECB's authorization is highlighted as the key macroeconomic reform that should enable a solution to this problem. Instead of only focusing on inflation, the ECB should, with its wider authorization, allow the financial sector to operate in the direction of crediting primarily productive parts of the economy, thus encouraging full employment, growth, and stability. Commitment to common prosperity means that we need to work on eliminating the growing inequality problem that is present everywhere in the world. The fact is that the economic, legal and political frameworks of the eurozone do not allow the mitigation of this problem. In other words, the free flow of goods and capital, without tax harmonization, reinforces the problem (Štiglic, 2016).

\section{THE INTERNATIONALIZATION OF THE YUAN}

The growing role of Asia in the world economy (primarily the position of China - the world's largest exporter and the dynamic growth of the Chinese economy) has contributed to the increase in the internationalization of the yuan and an attempt to reduce the impact of the dollar. As there were attempts in the 1980s and 1990s to internationalize the yen, it is considered that in the 21st century China has taken certain steps leading to the gradual 
internationalization of the yuan. The National Bank of China sees the complete convertibility of the yuan as a process consisting of three steps:

- the yuan as a global trading currency - as the yuan develops as a trading currency, companies outside China will gradually become used to using it for paying for goods and services;

- the yuan as a global investment currency - the goal is to allow more free investment of the yuan. Investors will be able to use their reserves in the yuan across the border. Global companies want their earnings in China to be convertible to other currencies;

- the yuan as a global reserve currency - the government wants the status of its currency to match the position of the country that is becoming an economic leader.

In a way, China wants to challenge the dollar as a reserve currency (Love and Chen, 2017). Although the complete internationalization of the yuan is probably still far away (the question arises as to whether China wants this now and how long should it take this to achieve), it is certain that what has been done is changing the situation on the international scene. The growing role of the yuan is primarily reflected in the fact that exporters can invoice the goods they sell in the yuan, gradually opening the gate for a foreign capital inflow (the yuan is used for the calculation of investments through offshore zones), bilateral swap arrangements in the yuan are created with the central banks of the main trading partners, enabling the calculation and payment in the yuan in mutual trade and spreading the circle of currencies which the yuan is directly exchanged for without the intermediation of the dollar (Kovačević, 2014).

In the last two years, two very important things have happened, both in favor of the internationalization of the yuan - the International Monetary Fund has included the yuan into the basket of the currencies that determine the value of special drawing rights and the European Central Bank, as one of the most powerful central banks in the world, has invested a certain portion of its foreign exchange reserves in the yuan, selling a small portion of dollar receivables. It is part of the ECB's strategy to diversify its foreign exchange reserves and add China's currency. Although this investment represented only about $1 \%$ of their total foreign exchange reserves (of around 68 billion euros), and the dollar still makes up the majority of the foreign exchange reserves of this institution, this was the major incentive for China. This points to the growing confidence in the yuan market as a world reserve currency and the acceptance of China as a global economic power in Europe. For this reason, the yuan is accepted by an increasingly greater number of countries as a reserve currency. However, this still does not mean that the yuan will become the dominant reserve currency instead of the dollar (even the euro) in a near future (Figure 8). As an accounting unit, it is used for about $2 \%$ of international payments, although the share of China's GDP in the world in the last few years has been much higher and has amounted to over $17 \%$. Although the largest trader in the world, China only accounts for $20 \%$ of its foreign trade in the yuan, which is much less than about $60 \%$ of the eurozone foreign trade in euros, or about $40 \%$ of Japan's foreign trade in the yen (Huang, 2017).

The international role of the yuan is considered to still be limited in comparison with the dollar and the euro. The further internationalization of the yuan will depend on whether China will succeed in diverting the economy from investment to consumption in order to avoid a medium-income trap. In addition, the still-present restrictions in the capital account diminish the attractiveness of the yuan for foreign investors (Kovačević, 2015).

The full convertibility of the yuan, i.e. its being a reserve currency to a proper extent, requires further work in the following areas: maintaining economic stability in terms of stable economic growth, a stable exchange rate, and a low inflation rate. China is increasing its share in world trade and an increase in the size of its national economy is important to its trading partners, which clearly justifies a greater use of the yuan; deepening capital markets and accelerating the integration of its own and offshore capital markets; increasing efforts to create solid and reliable legal and regulatory frameworks. The internationalization of the yuan is a decisive goal of the national policy 


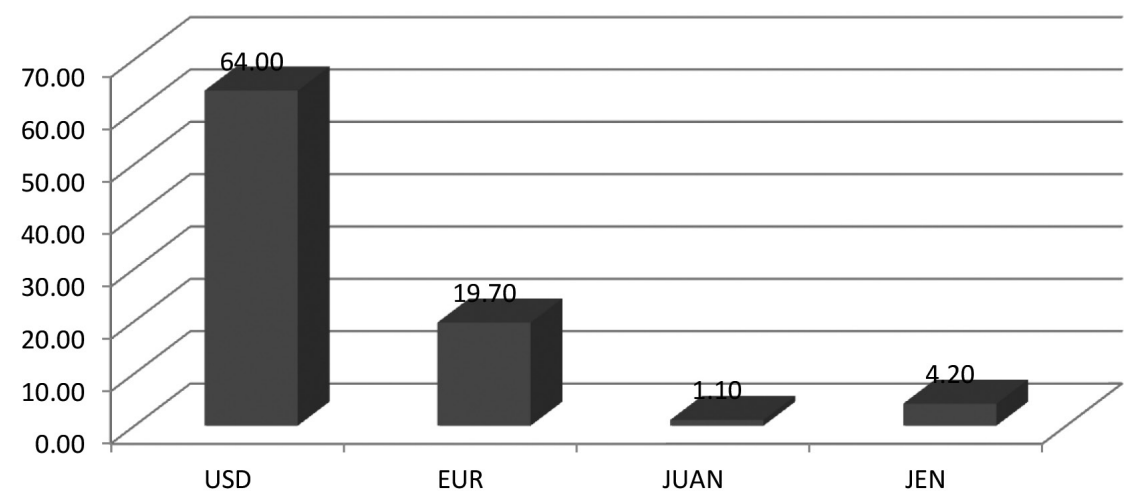

Figure 8 The percentage share of the most important currencies in the world foreign exchange reserves, 2016.

Source: ECB, 2017

of China's government, which is taking place at a faster pace than expected. In the upcoming period, the improved industry infrastructure, reinforced financial regulations, well-structured deposit insurance schemes, improved market-driven exit mechanisms for financial institutions etc. (Huang, 2017) should be expected.

\section{THE IMPACT OF GLOBALIZATION ON THE INTERNATIONAL MONETARY SYSTEM}

Over the past half-century, globalization has had a significant (primarily positive) impact on people's lives. The problem is that the resulting gains are not evenly distributed at either the regional or the national level. Over time, an increase in international trade and financial openness has happened in parallel. On the one hand, financial connections in the form of international payments and loans have greatly facilitated trade, whereas at the same time the accumulation of international assets and liabilities has occurred. All of this has made the countries that are more open-minded become more financially open. The relationship between real and financial openness developed with the degree of integration and development. In this context, we can speak of the three phases of globalization so far. The first, the most basic phase involved trade in goods and finished products and correspondingly simple international financial links, such as crossborder payments. The second phase involved more complex trade and financial links. It involved trade in semi-finished products and services, linked to the fragmentation of production between the countries that was led by efficiency and with the corresponding financial arrangements. The third phase concerned the increasing use of financial transactions to actively manage balance sheet positions. All of the three phases of globalization share some common elements. One of them is the use of the world currency.

As the dominant world currency, the dollar is used for the denomination of not just about one-half of the world trade, but also about one-half of global cross-border banking receivables and over $60 \%$ of the foreign currency assets of central banks, as well as over $90 \%$ of transactions in the foreign exchange market. As a result, the dollar continues to play the key role in determining global financial conditions. Globally active financial institutions are another common element. They function in many countries, across continents. Due to their international presence and sophistication, they facilitate the transfer of funds and financial risks at a global level. The balances managed at a consolidated level create close international financial links (Bank for International Settlements, 2017). The major problem is the growing separation between the real and the financial sectors, significantly higher turnover in financial markets and an insufficiently good regulation at the global 
level. On the one hand, new financial instruments and significant financial transactions enable easier financing, whereas on the other hand, this leads to a faster transfer of problems between certain parts of the market.

In addition to all of the foregoing changes that occurred in the international financial market, according to the data of 2016, the dollar remains the world's most important currency (Figure 9). Although it has managed to rank the second, the euro, as the unique European currency, has not yet created a major synergy effect and is still too far behind the dollar. On the other hand, as far as the Asian block is concerned, it is notable that there is no unity (the yen is still present), the internationalization of the yuan has only recently started and it needs time to pass for China's yuan to achieve a more significant share.

\section{CONCLUSION}

Globalization, present in all segments of society, greatly influences the significant spillovers of the monetary policy effects between countries. For this reason, the strengthening of international cooperation, as well as the occasional joint actions of monetary authorities, has become inevitable. The important question of how the international monetary system will develop in the coming period remains. Will the euro and the yuan be able to expand their influence? Will this be a sustainable process and will this happen by reducing the impact of the dollar? In addition, some new instruments, such as virtual currencies (primarily bitcoins), can also be a form of a challenge in the upcoming period.

At present, the dollar can be said to still have the two major advantages when retaining the central role in the international monetary system is concerned (even if China's economy is considered to be larger than America's). The first advantage is that the existence of single dominant international money is considered as a natural monopoly and that the introduction of the second or third reserve currency would raise the administrative costs of making international payments between different countries around the world. Second, there is a great advantage for the national currency that already has the status of an international currency. When most banks in private transactions use the dollar as an intermediate currency in exchange for a second and third currency, transaction costs decrease in these markets and their liquidity increases as well. With this decrease in costs, the remaining banks are attracted to using the dollar (McKinnon, 2013).

As far as Europe is concerned, it must act collectively in order to move forward (and as quickly as possible).

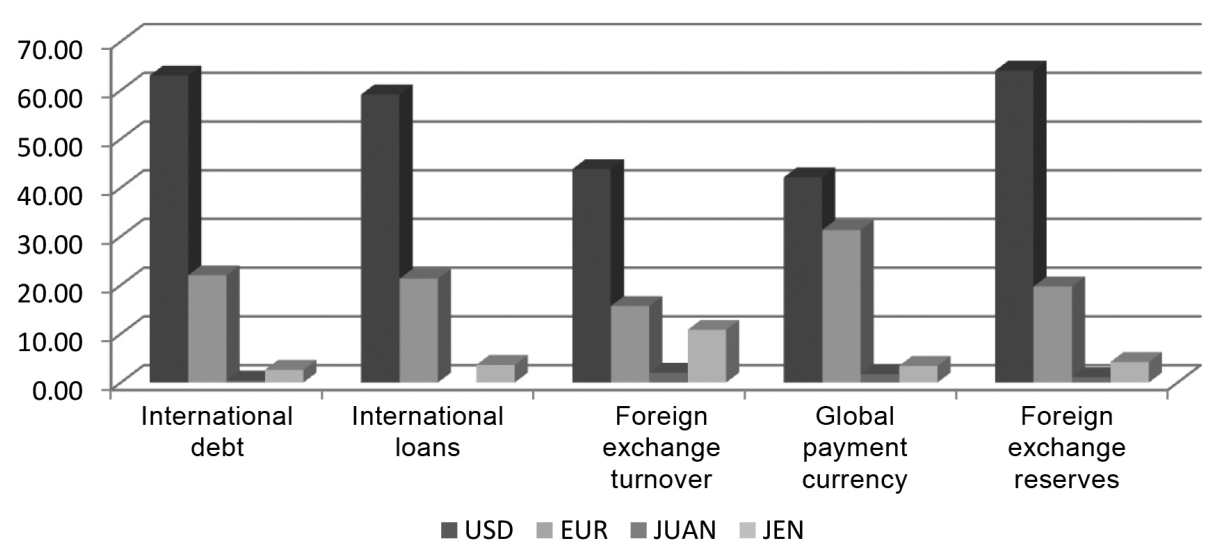

Figure 9 The percentage share of the most important currencies in the international monetary system, 2016. 
The goal is for the EU as a whole to be greater than the sum of its parts (individual countries) in economic, social, technological, commercial and political terms. The euro as a common currency, or the EMU, can be very important on this path. However, in order for this to happen, serious economic and political reforms are necessary.

China's yuan is obviously increasing its international impact, especially among the BRICS countries. In spite of that, we still cannot speak of an Asian block linked to the yuan. However, some kind of the transition of the international monetary system from the bipolar (the US dollar and the euro) to the tripolar currency block (including the yuan) is obviously in progress.

In addition to the fact that a lot has changed since the beginning of the Bretton Woods International Monetary System and that it is constantly criticized for the significant benefits that the United States has for the reason of the fact that the dollar has the key role in the international monetary system and global liquidity, it is concluded that the position of the dollar as the most important world currency has not yet been endangered, which confirms the established hypothesis. The liquidity, reliability and depth of the US financial market continue to put the US government securities at the forefront. Although developing countries and countries in transition increase the amount of foreign exchange reserves (as a response to the increasingly more frequent crises and a faster transfer of these crises) and want to make the currency diversification of their assets, the above presented facts enable the dollar to retain the position of the dominant currency of the world's foreign exchange reserves (Kovačević, 2014). Although the US current account deficit is large and there is the so-called "factory error" when the dollar is concerned (having confidence in the currency of a country that has a huge current account deficit), a conclusion can be drawn that the position of the dollar does not depend on the abovementioned deficit as much as it does on the fact that no other currency is still significantly increasing its share in the international financial market.

\section{ACKNOWLEDGEMENT}

This paper is part of the Integrated and Interdisciplinary Research Project (No. III 47005), funded by the Ministry of Education, Science and Technological Development of the Republic of Serbia.

\section{REFERENCES}

Adams, C., \& Park, D. (2009). Causes and consenquences of global imbalances: Perspective from developing Asia. Asian Development Bank Economics, Working Paper Series No. 157. doi.org/10.2139/ssrn.1611424

Bank for International Settlements. (2017). 87 $7^{\text {th }}$ Annual Report. Basel, Bank for International Settlements.

Blanchard, O., Giavazzi, F., \& Sa, F. (2005). International investitors, the U.S. current account, and the dollar. Global Current Account Imbalances and Exchange Rate Adjustments. Brookings Papers on Economic Activity No 1, pp. $1-49$.

Bureau of Economic Analysis. (2018). Retrieved March 3, 2018, from https://www.bea.gov/international/bp_web/tb_ download_type_modern.cfm?list=2\&RowID $=144$

European Central Bank (ECB). (2017). The international role of the Euro. Retrieved March 5, 2018, from https://www. ecb.europa.eu/pub/pdf/other/ecb.euro-internationalrole-201707.pdf

Farhi, E., Gournchas, P-O., \& Rey, H. (2011). Reforming the international monetary system. London, UK: Centre for Economic Policy Research.

Filipović, S. i Garić, D. (2014). Analiza uzroka globalne platnobilansne neravnoteže. Poslouna ekonomija, 8(2), 277300. doi:10.5937/PosEko1402277F

Goldberg, L. (2010). Is the international role of the dollar changing? Current Issues in Economics and Finance, 16(1), 1-7.

Goldberg, L. (2011). The international role of the dollar: Does it matter if this changes? Staff Report No. 522. doi.org/10.2139/ ssrn.1945339

Huang, Y. (2017). The growing role of RMB in global reserve currency system. Retrieved January 12, 2018, from http:// www.atimes.com/growing-role-rmb-global-reservecurrency-system/ 
International Monetary Fund. (2017). World Economic Outlook Database.

Jovanović Gavrilović, P. (2012). Međunarodno poslovno finansiranje. Beograd, Republika Srbija: Ekonomski fakultet Univerziteta u Beogradu.

Kovačević, R. (2011). Reforma međunarodnog monetarnog sistema. Bankarstvo, 9-10, 26-51.

Kovačević, R. (2014). Dolar kao svetska rezervna valuta izazovi i perspective. Bankarstvo, 6, 16-43.

Kovačević, R. (2015). Karakteristike i savremeni izazovi međunarodnog monetarnog i finansijskog sistema. Bankarstvo, 4, 18-39.

Krugman, P. (1984). The international role of the dollar: Theory and prospect. In J, Bilson, \& R. Marston (Eds.). Exchange Rate Theory and Practice (pp. 261-278). Chicago, USA: University of Chicago Press.
Love, H., \& Chen, C. (2017). Chinese renminbi internalization - Guide to recent developments. International Services Chinese Renminbi Internationalization. Retrieved February 8, 2018, from https://www.pnc.com/content/dam/pnc-ideas/ articles/CIB-TM-China-Whitepaper-Update.pdf

McKinnon, R. (2013). The Unloved Dollar Standard. New York, NY: Oxford University Press.

Obstfeld, M., \& Rogoff, K. (2005). Global current account imbalances and exchange rate adjustments. Brookings Papers on Economic Activity, 36(1), 67-123.

Tovar, C., \& Nor, T. (2018). Reserve currency blocks: A changing international monetary system? Working Paper No. 18/20, International Monetary Fund.

Triffin, R. (1978). Gold and the dollar crisis: Yesterday and tomorrow. Princeton, N.J: Princeton University.

Štiglic, Dž. (2016). Evro - kako zajednička valuta ugrožava budućnost Evrope. Novi Sad, Republika Srbija: Akademska knjiga.

$$
\begin{array}{r}
\text { Received on } 16^{\text {th }} \text { March } 2018, \\
\text { after revision, } \\
\text { accepted for publication on } 23^{\text {rd }} \text { April } 2018 . \\
\text { Published online on } 26^{\text {th }} \text { April } 2018 .
\end{array}
$$

Nenad Jankovic is an assistant professor at the Faculty of Economics at the University of Kragujevac. He teaches International Finance. He received the title of a Doctor of Economic Sciences at the Faculty of Economics, University of Kragujevac. The fields of his scientific interest are international economics, international finance, and the foreign exchange rate policy. 


\title{
PERSPEKTIVE MEĐUNARODNOG MONETARNOG SISTEMA
}

\author{
Nenad Janković* \\ Ekonomski fakultet Univerziteta u Kragujevcu
}

Tokom XX-og veka dolar je dobio status najznačajnije svetske valute. Zbog toga, bretonvudski međunarodni monetarni sistem se zasnivao na dolaru. Međutim, 70-ih godina XX-og veka, situacija se, u velikoj meri, promenila - velika tražnja za dolarima se smanjila, valute najznačajnijih evropskih zemalja su postale konvertibilne, višestruko se povećao obim međunarodne trgovine, liberalizovani su međunarodni tokovi kapitala, ukinuta je spoljna konvertibilnost dolara u zlato i valute su počele da fluktuiraju. Na taj način, izvorni bretonvudski međunarodni monetarni sistem prestao je da postoji. Pored tih promena, na funkcionisanje međunarodnog monetarnog sistema $u$ velikoj meri utiče $i$ to što su SAD iz godine $u$ godinu počele da beleže sve veće iznose deficita tekućeg računa i tokom 80-ih godina XX-og veka su prešle iz pozicije neto poverioca u poziciju neto dužnika, što je na tlu EU stvoren evro i što je Kina postala najveći svetski izvoznik i jedna od najvećih (ako ne i najveća) svetskih ekonomija. Zbog svega navedenog, u radu su sistematizovane teorijske pretpostavke međunarodnog monetarnog sistema, ispitana je uloga ostalih svetskih valuta, u nastojanju da se odgovori na pitanje: zašto je dolar i dalje dominantna svetska valuta?

Ključne reči: bretonvudski međunarodni monetarni sistem, dolar, evro, juan, svetska valuta

JEL Classification: F31, F32, F33, F62, F65

\section{UVOD}

Status svetske valute nije isključivo definisan relativnom veličinom zemlje i njenim prisustvom na međunarodnim tržištima. Iz tog razloga, iako su Sjedinjene Američke Države (SAD) prevazišle Veliku Britaniju po veličini u ranoj fazi XX-og veka, $\mathrm{u}$ tom trenutku, dolar nije uspeo da preuzme ulogu

* Korespondencija: N. Janković, Ekonomski fakultet Univerziteta u Kragujevcu, Đ. Pucara 3, 34000 Kragujevac, Republika Srbija; e-mail: njankovic@kg.ac.rs vodeće valute od funte sterlinga, nego se to desilo kasnije (Goldberg, 2011). Bretonvudski međunarodni monetarni sistem je nastao nakon Drugog svetskog rata, kada je postalo jasno da prethodna, na neki način, samoregulišuća verzija zlatnog standarda ne može da opstane. Nedovoljno rezervi da bi se garantovala konvertibilnost celokupnog papirnog novca $\mathrm{u}$ zlato $\mathrm{u}$ međuvremenu je uslovila pojavu zlatno-polužnog i zlatno-deviznog standarda. Istovremeno, dešavanja za vreme, i nakon Prvog i Drugog svetskog rata doprinela su da SAD postanu 
vojna, ekonomska, finansijska i tehnološka velesila, tako da ne treba da čudi što je dolar, ipak, postao najvažnija svetska valuta XX-og veka. Ključne su bile sledeće dve činjenice - postojala je velika tražnja za dolarima i postojala je konvertibilnost dolara u zlato. Jednostavno, dolar je postao svetski novac - u dolarima su se iskazivali devizni pariteti drugih valuta, vršila su se međunarodna plaćanja, fakturisale su se cene, držale su se monetarne rezerve, štedelo se u dolarima i zlatno-devizni sistem je postao zlatnodolarski.

Međutim, već početkom 70-ih godina XX-og veka, dosta stvari se promenilo - valute najznačajnijih evropskih zemalja su postale konvertibilne, višestruko se povećao obim međunarodne trgovine, liberalizovani su međunarodni tokovi kapitala, ukinuta je spoljna konvertibilnost dolara u zlato, valute su počele da fluktuiraju - na neki način, izvorni bretonvudski međunarodni monetarni sistem je prestao da postoji. Ipak, pored svih ovih promenjenih okolnosti, pored činjenice da SAD iz godine u godinu beleže ogroman spoljnotrgovinski i budžetski deficit, dolar i dalje uživa opšte poverenje u svetu i prihvaćen je kao sredstvo plaćanja, obračuna i rezervi. Tako, i u XXI veku dolar ostaje, za sada, najznačajnija svetska valuta. Postavlja se pitanje: kako je to moguće kad dolarski standard niko ne voli? Iako je mnogo godina prošlo od napuštanja izvornog bretonvudskog međunarodnog monetarnog sistema, neki drugi, zvanično nije uspostavljen. Smatra se da je neophodno izvršiti određene reforme - stvoriti međunarodni monetarni sistem koji će smanjiti uticaj dolara i uzeti $\mathrm{u}$ obzir sve novonastale promene $\mathrm{u}$ međunarodnim ekonomskim odnosima. Prema R. Triffinu (1978), kada je u pitanju međunarodna monetarna reforma, postoje dva osnovna pristupa - monetarna reforma na svetskom nivou i regionalna monetarna saradnja ili integracija. Za sada, kreiranje neke vrste svetskog novca izgleda malo verovatno - ne zna se ko bi ga kreirao i ko bi ga kontrolisao. Jednostavno, na svetskom nivou nema konsenzusa. S druge strane, postoje razmišljanja o stvaranju neke vrste multivalutnog međunarodnog monetarnog sistema, gde bi, zahvaljujući svojoj poziciji u međunarodnom ekonomskom poretku, evro i kineski juan trebalo da zauzmu svoje pozicije.
Cilj ovog rada je da razjasni teorijske pretpostavke vezane za postojanje bretonvudskog međunarodnog monetarnog sistema, kao i da ukaže na značaj promena koje su nastale u međuvremenu.

Shodno navedenom cilju istraživanja, kao ključna se može izdvojiti sledeća hipoteza:

H: Uprkos činjenicama da je došlo do ukidanja spoljne konvertibilnosti dolara u zlato, stvaranja evra kao zajedničke valute evrozone i da je Kina postala najveći svetski izvoznik, dolar ostaje najznačajnija svetska valuta.

U radu će biti primenjena kvalitativna metodologija utemeljena na proučavanju i deskriptivnoj analizi istraživačkog problema. Istraživanjem ce biti proučena relavantna, inostrana i domaća literatura zasnovana na teorijskim uopštavanjima i iskustvima autora koji su se bavili predmetnom problematikom. Polazeći od relavantne literature, analiziraće se da li je, pored svih promenjenih okolnosti $u$ međunarodnom monetarnom sistemu, dolar i dalje dominantan, odnosno, šta je potrebno da bi još neke valute, pre svega, evro i juan, formirale multivalutni međunarodni monetarni sistem.

Rad je organizovan na sledeći način: u drugom delu rada će biti reči o najznačajnijim karakteristikama izvornog bretonvudskog međunarodnog monetarnog sistema, treći deo rada se bavi uzrocima i posledicama neravnoteže tekućih računa pojedinih zemalja, četvrti i peti deo ispituju potencijal evra i juana kao međunarodne valute, šesti deo rada se bavi uticajem globalizacije na međunarodni monetarni sistem i u sedmom delu se izvode zaključci.

\section{IZVORNI BRETONVUDSKI MEĐUNARODNI MONETARNI SISTEM}

Klasični ekonomisti tvrde da novac ima tri funkcije služi kao sredstvo razmene, kao jedinica obračuna i kao čuvar vrednosti. Uloga međunarodnog novca je ista - koristi se za izmirenje međunarodnih plaćanja, da se fiksiraju cene, i drži se kao likvidna aktiva za međunarodne transakcije. Dodatna dimenzija je 
obezbeđena razlikom u ponašanju privatnog sektora i centralnih banaka. Na osnovu navedenog, može se reći da dolar, kao najznačajnija međunarodna valuta, obavlja šest funkcija. Dolar kao sredstvo razmene $u$ privatnom sektoru predstavlja posrednika između valuta, dok kupovinomi prodajom od strane centralnih banaka predstavlja valutu kojom se interveniše na tržištu. Trgovinski ugovori denominirani u dolarima ga predstavljaju kao fakturnu valutu (kod privatnog sektora), dok centralnoj banci služi da domaću valutu izrazi u dolarima (fiksira za dolar - devizni kurs). Na kraju, ukoliko se posmatra kao čuvar vrednosti, privatna lica drže likvidnu aktivu denominiranu u dolarima (neka vrsta bankarske uloge), dok centralne banke drže dolar kao rezervnu valutu (Krugman, 1984).

Sve dok je postojala potpuna zamenljivost dolara $\mathrm{u}$ zlato, centralne banke su akumulirale dolarsku aktivu i bretonvudski monetarni sistem je funkcionisao bez problema. Poverenje u spremnost SAD da konvertuju dolare u zlato doprinela je povećanju udela dolara u deviznim rezervama. Međutim, već početkom 60ih godina XX-og veka, javio se problem dugoročnog poverenja $u$ održivost ovakvog sistema. Zbog porasta dolarske aktive kod centralnih banaka $\mathrm{u}$ svetu, iznos dolarskih rezervi je nadmašio američke zalihe zlata, čime je Centralna banka SAD (FED) bila onemogućena da otkupi sve dolare (ukoliko bi strane centralne banke želele da sve svoje dolarske rezerve zamene za zlato) (Kovačević, 2015). Na taj način, SAD su bile primorane da ukinu spoljnu konvertibilnost dolara $u$ zlato, čime je srušen jedan od stubova izvornog bretonvudskog međunarodnog monetarnog sistema. U narednom periodu, to je bio sistem koji je sve više počivao na poverenju - bilo je neophodno da se veruje $u$ stabilnost dolara. Čim dođe do poremećaja, krize poverenja, takav sistem više ne funkcioniše kako treba. Međutim, s druge strane, značajna upotreba dolara je upravo vodila toj nestabilnosti sistema. Zadovoljavanje rastuće potrebe za međunarodnom likvidnošću je vršeno sve većom količinom dolara koja je ostajala van SAD, što je opet, s druge strane, uvećavalo problem u platnom bilansu SAD. Kumuliranje platnobilanskog deficita u SAD i porast dolarskih potraživanja stranaca su dovodili do smanjenja poverenja u dolar. Može se reći da ovakva situacija predstavlja jedan od značajnijih nedostataka ovako uspostavljenog međunarodnog monetarnog sistema („fabričku grešku” kako ističu pojedini autori) - valuta zemlje koja ima veliki (i sve veći) deficit treba da uživa opšte poverenje u svetu i da tamo bude prihvaćena kao sredstvo plaćanja, obračuna i rezervi (Jovanović Gavrilović, 2012).

U tom trenutku, postavljalo se pitanje kakav će položaj dolara biti nakon prestanka konvertibilnosti dolara $\mathrm{u}$ zlato, odnosno, da li će dolar ostati opšteprihvaćena valuta i da li će SAD i dalje moći da finansiraju deficit tekućeg računa bez pokrića. Međutim, SAD su iskoristile svoj uticaj na zemlje OPEC-a (pre svega, na Saudijsku Arabiju) i obavezale ih da naftu prodaju isključivo u dolarima. Umesto zlata, nafta (,,crno zlato”) je, kao pokretač svetske ekonomije i trgovine, postala podloga modifikovanog međunarodnog monetarnog sistema. S obzirom da nije bilo fiksne veze između nafte i dolara, SAD je bilo omogućeno da vode još labaviju fiskalnu politiku, a dolar je, zahvaljujući tzv. petrodolarskom standardu, ostao najznačajnija svetska rezervna valuta (Filipović i Garić, 2014).

Pojedini ekonomisti smatraju da nedostatak diversifikacije rezervnih valuta predstavlja slabost i ranjivost ovakvog međunarodnog monetarnog sistema, zato što to može dovesti do nelikvidnosti, preteranih privilegija, pogrešnih tokova kapitala i podsticanja slabe fiskalne discipline u zemljama čije valute se koriste kao rezervne. Međutim, prema drugima, dominacija nekoliko valuta je dobra, jer dominantne valute obezbeđuju visoko kvalitetnu i sigurnu aktivu u vreme finansijskih kriza. Ipak, nezavisno od ovih suprotnih stavova, globalna ekonomija postaje sve više multipolarna. Značajne strukturne promene su podržale ovu transformaciju - uključujući brzo širenje i povećanje povezanosti globalne ekonomije i finansijskih tržišta. $U$ tom kontekstu, ključno pitanje je da li će transformacija globalne ekonomije rezultirati diversifikovanijim sistemom rezervnih valuta (Tovar \& Nor, 2018)?

Zaključak je da, što se korišćenja dolara tiče, postoji veliki paradoks. Iako niko ne voli dolarski standard, dolar nastavlja da se koristi. Zemlja koja fiksira svoj 
devizni kurs prema dolaru će težiti da interveniše na deviznom tržištu u dolarima i da akumulira rezerve u dolarima. Ovoj zemlji će dolar biti izbor za komercijalne i finansijske transakcije zato što na taj način ograničava rizik promene deviznog kursa (Farhi, Gournchas \& Rey, 2011). Uprkos turbulencijama na tržištima širom sveta i znatnim oscilacijama $u$ vrednosti dolara u proteklom periodu, važnost dolara se nije značajno smanjila (ni ako se koristi kao valuta za koju se vezuje vrednost domaće valute, ni kao međunarodna rezervna valuta) (Goldberg, 2010). Iz tog razloga, uhodani postupci obračuna i mehanizma međunarodnih plaćanja pomažu dolaru da zadrži poziciju koju je stekao u međunarodnoj trgovini. Kao glavni monetarni mehanizam, on osigurava da međunarodna trgovina ostane na kakav-takav način multilateralna, pre nego usko bilateralna. Jednostavno rečeno, ovakav sistem je, još uvek, suviše dragocen da bi se izgubio, i suviše težak da bi se zamenio (McKinnon, 2013).

\section{UZROCI I POSLEDICE VELIKE NERAVNOTEŽE TEKUĆIH RAČUNA POJEDINIH ZEMALJA}

Neravnoteža tekućih računa pojedinih zemalja je jedna od ključnih makroekonomskih neravnoteža, koja je u značajnoj meri uticala na pojavu poslednje finansijske krize. U većini slučajeva, neravnoteža je skoncentrisana u maloj grupi regiona ili zemalja, ali prava slika se dobija ako se vidi koje su to zemlje u pitanju. Zbog veličine sopstvene ekonomije, SAD i deficit njihovog tekućeg računa mogu predstavljati veliki problem po održivost postojećeg sistema. $\mathrm{Ne}$ postoji jasno definisana granica održivosti deficita tekućeg računa. Jednostavno, nečiji deficit će biti održiv sve dok poverioci imaju poverenja u dužnika. Ipak, pojedini ekonomisti smatraju da deficit tekućeg računa koji je veći od 5\% BDP-a, predstavlja problem. U 2006. deficit tekućeg računa SAD je prešao tu granicu i dostigao skoro 6\% BDP-a SAD. U tom trenutku, taj deficit je predstavljao oko $75 \%$ suficita tekućih računa Nemačke, Japana, Kine i svih ostalih suficitarnih zemalja na svetu (Obstfeld \& Rogoff,
2005). Po definiciji, deficit/suficit tekućeg računa jednak je negativnoj/pozitivnoj neto štednji. Na taj način posmatrano, globalna neravnoteža se može videti kao stalno finansiranje potrošnje SAD neto štednjom suficitarnih zemalja. Globalna neravnoteža je omogućila globalnoj agregatnoj tražnji da održi korak sa brzim širenjem globalne agregatne ponude (pre svega), zbog integracije Kine i Indije u svetsku ekonomiju (Adams \& Park, 2009). U tim godinama dve najvažnije stvari koje su uticale na veliki deficit tekućeg računa SAD-a su bile povećanje američke tražnje za inostranim dobrima i povećanje inostrane tražnje za američkom aktivom (Blanchard, Giavazzi \& Sa, 2005). Mnogi ekonomisti ovakav vid globalne nejednakosti smatraju neodrživim. Smatra se da ako stranci (i vlade i privatni sektor), iz nekog razloga, prestanu da kupuju dolarsku aktivu, to može pokrenuti značajan pad vrednosti dolara na deviznim tržištima i dovesti $u$ pitanje sposobnost SAD da pozajmljuje iz inostranstva. Istovremeno, iako strane centralne banke drže skoro polovinu neizmirenih hartija od vrednosti američkog Trezora, SAD su jedna od retkih zemalja koja se može još više zaduživati, zato što se zadužuju u sopstvenoj valuti i zato što su imune na uobičajeni rizik sa kojim se suočavaju druge zemlje dužnici, čiji su dugovi u stranoj valuti. Pored toga, postoji mogućnost i da FED naštampa dovoljno novca kako bi dug bio otplaćen (McKinnon, 2013).

Iznenađujuće, uprkos nekim političkim i ekonomskim neslaganjima sa SAD, može se zaključiti da je Kina manje/više nenamerno postala stub ovako uspostavljenog dolarskog standarda. Ova tvrdnja se ogleda u sledećem (McKinnon, 2013):

- Efekat grudve: Velika ekspanzija kineske trgovine sa ostalim tržištima u nastajanju i zemljama koje proizvode primarne proizvode širom sveta, gde je dolar valuta kojom se fakturišu dobra, kao i obračunska valuta za obavljanje međunarodnih plaćanja. To redukuje transakcione troškove i povećava likvidnost tržišta baziranih na dolaru.

- Makrostabilizacioni efekat: Od 1994. Kina je uspešna u sprovođenju kontraciklične fiskalne (kreditne) politike, kojom je stabilizovala svoj rast BDP na visokom nivou, što, donekle, ublažava ciklične nestabilnosti koje dolaze iz SAD. 
- Finansijski efekat: Kina finansira veliki američki fiskalni deficit. Ako bi, prateći Kinu, stranci kolektivno prestali da kupuju obveznice američkog Trezora i ostalu dolarsku aktivu, nastala bi kreditna kriza u SAD.

Po pitanju jačine uticaja Kine na svetsku ekonomiju ne postoji jedinstveno mišljenje. Dok pojedini ekonomisti smatraju da je Kina već postala vodeća ekonomska sila, ima i onih koji smatraju da je neophodno da prođe još dosta godina kako bi, realno gledano, kineski uticaj bio veći od, pre svega, uticaja SAD. Svakako, Kina je postala najveći kreditor SAD i naredne slike ilustruju da se $\mathrm{u}$ XXI-om veku, gledano kroz odnos ove dve zemlje, dosta toga promenilo kada je u pitanju preraspodela ekonomske moći u svetu.

Na Slici 1 prikazano je kretanje BDP u ove dve zemlje u periodu 2000-2017, mereno u tekućim cenama, prema paritetu kupovne moći. Iako je na početku posmatranog perioda kineski BDP bio 2,7 puta manji od SAD, za svega 15 godina, kineski BDP je postao veći, da bi 2017, prema procenama International Monetary Fund-a (IMF), ta razlika bila skoro 4000 milijardi dolara. U posmatranom periodu, kineski BDP je porastao 6,25 puta, dok je BDP SAD porastao, svega, za 1,88 puta. Jedini pokazatelj po kome su SAD još uvek daleko ispred Kine je BDP per capita (takođe tekuće cene, prema paritetu kupovne moći) - Slika 2.
Prema procenama IMF-a, u 2017, BDP per capita u SAD je bio 59.495,34 dolara, a u Kini 16.624,41 dolar. Ipak, i ovde postoji značajna razlika kada se uporedi koliko je to povećanje iznosilo u odnosu na početak posmatranog perioda. BDP per capita je u Kini porastao 5,7 puta, a u SAD samo 1,63 puta, tako da je zaključak da se ta razlika smanjuje. Na osnovu navedenih podataka, primetno je da je finansijska kriza ostavila značajnije posledice po ekonomiju SAD - zabeležen je pad ovih pokazatelja u pojedinim godinama u SAD, dok je u Kini bio prisutan konstantni rast. Slika 3 ilustruje pomenutu preraspodelu ekonomske moći. Učešće ove dve ekonomije u svetskom BDP-u je povećano (prema procenama IMF-a) u posmatranom periodu za preko 5\%, i iznosi oko 33,55\%. Međutim, to povećanje je nastalo kao posledica smanjenja učešća BDP-a SAD za preko 5\% (sa 20,62\% na 15,29\%), i značajnog povećanja učešća BDP-a Kine od skoro $11 \%$ (sa 7,42\% na 18,26\%). Pored značajno većeg učešća kineskog BDP-a, na osnovu navedenih podataka može se zaključiti da je došlo i do povećanja koncentracije ekonomske moći, tako da BDP EU zajedno sa ove dve zemlje predstavlja oko 50\% svetskog BDP-a.

Slike 4, 5, 6 i 7 prikazuju zbog čega je prisutna već pomenuta velika neravnoteža tekućih računa pojedinih zemalja. Teorijski, u dugom roku, jedna zemlja bi trebalo da troši koliko i proizvodi, da

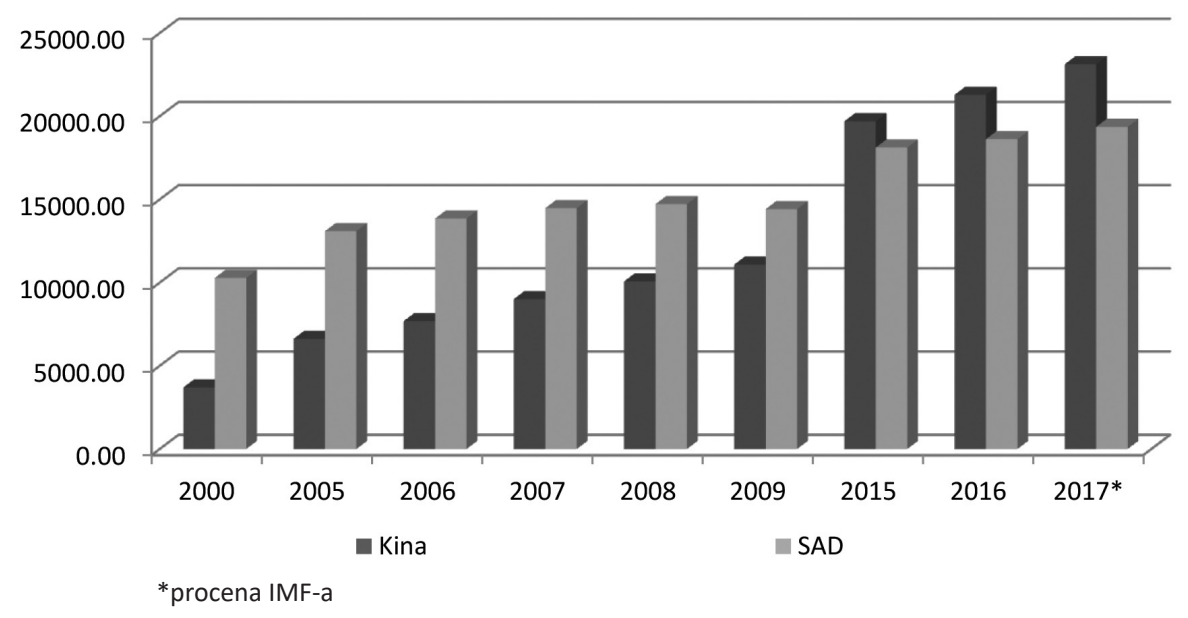

Slika 1 GDP, tekuće cene, PPP, milijarde dolara

Izvor: International Monetary Fund, 2017 


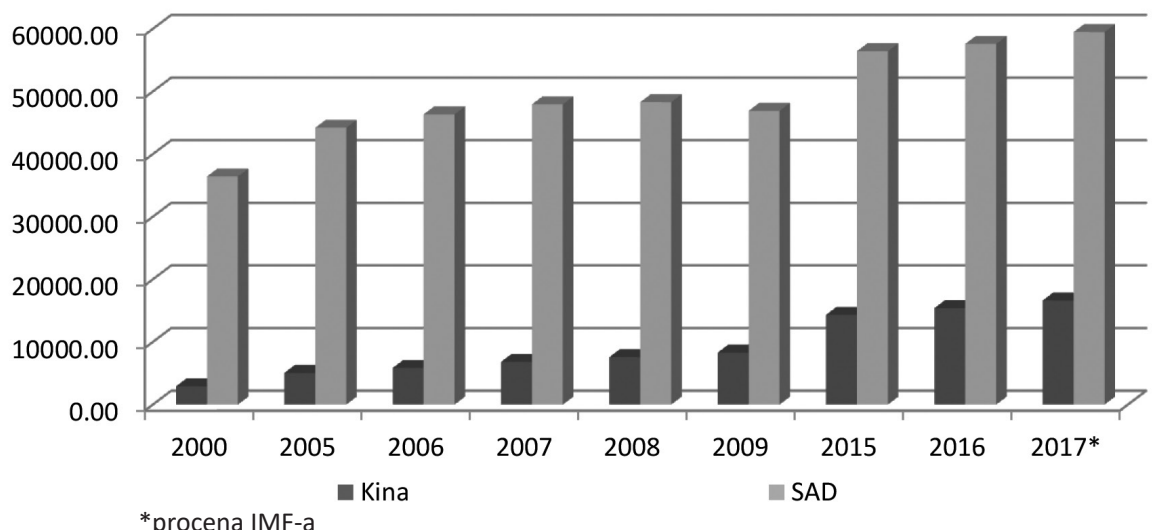

Slika 2 GDP per capita, tekuće cene, PPP, u dolarima

Izvor: International Monetary Fund, 2017

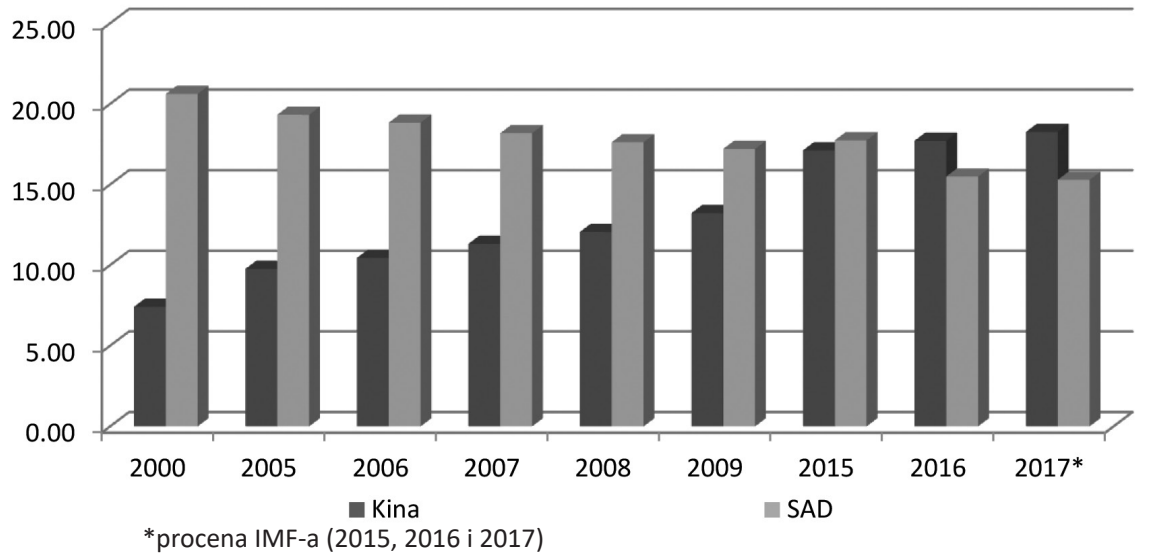

Slika 3 GDP (PPP), udeo u svetskom BDP

Izvor: International Monetary Fund, 2017

investira koliko i štedi. Međutim, u praksi to, najčešće, nije slučaj i zato postoje deficitarne i suficitarne zemlje. Zbog veličina svojih ekonomija, SAD i Kina su veoma značajni predstavnici ovih grupacija. U posmatranom periodu, investicije u Kini su iznosile, prosečno, $42,19 \%$ BDP, dok su u SAD iznosile svega 21,83\% BDP. Istovremeno, u Kini, štednja je učestvovala $u$ BDP prosečno sa $47,23 \%$, za razliku od SAD, gde je to učešće iznosilo $17,05 \%$. Očigledna je asimetrična pozicija ove dve zemlje - Kina ima značajan višak novca za ulaganja $u$ inostranstvu (najviše ga i ulaže $\mathrm{u}$ hartije od vrednosti Trezora SAD), dok investiciona aktivnost SAD, u najvećoj meri, zavisi od tuđeg novca. Najveći plasman investicija, Kina vrši na finansijsko tržište SAD zbog statusa koji dolar ima i činjenice da je to tržište najrazvijenije na svetu. Time se podiže likvidnost ovog tržišta i redukuje nivo kamatne stope na tom tržištu. Međutim, na taj način se generiše i potrošnja privrede SAD koja se većim delom nadoknađuje upravo uvozom iz Kine. S druge strane, Kina povećava tražnju za dolarom i dovodi do apresijacije dolara u odnosu na juan, čime juan postaje još više potcenjen, a kineski izvoz na tržište SAD još konkurentniji. Upravo je ta (ne)dokazana potcenjenost 


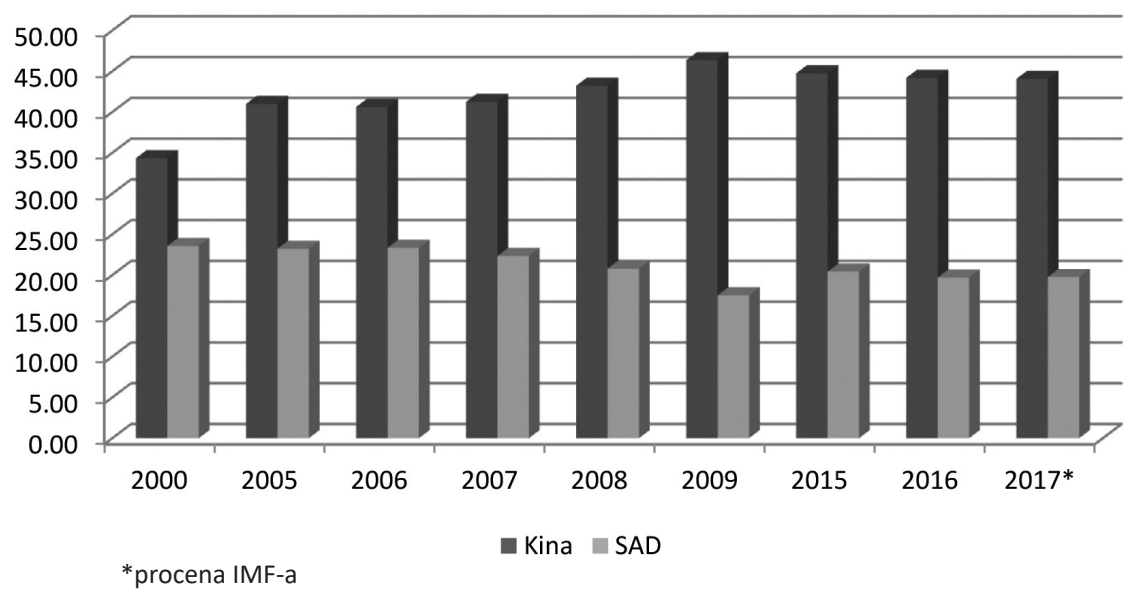

Slika 4 Ukupne investicije, \% BDP-a

Izvor: International Monetary Fund, 2017

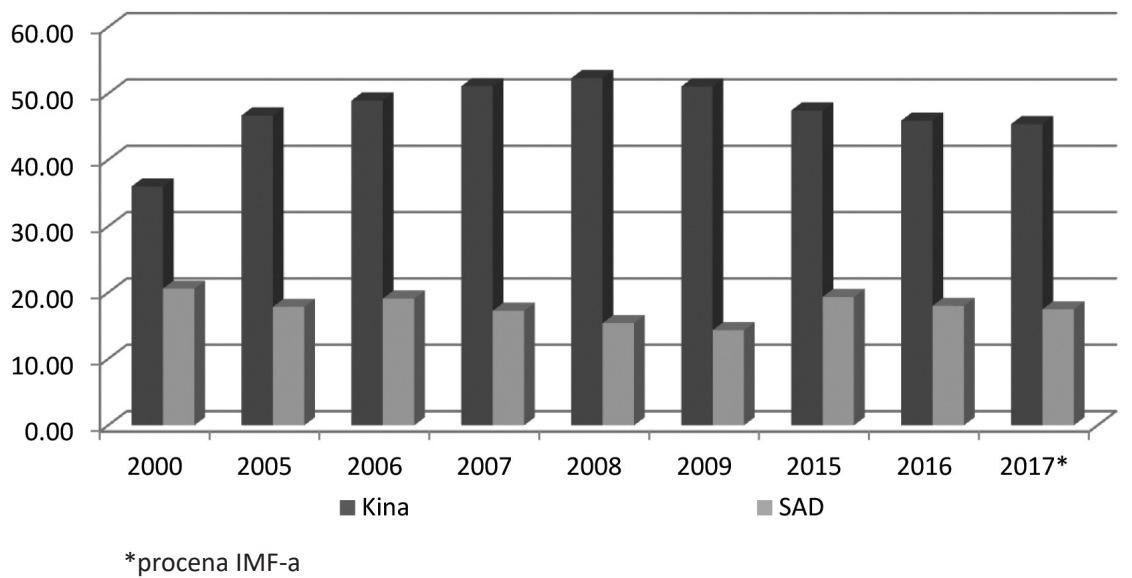

Slika 5 Bruto nacionalna štednja, \% BDP-a

Izvor: International Monetary Fund, 2017

juana jedna od ključnih tačaka spora između ovih zemalja (Filipović i Garić, 2014).

Javni dug obe zemlje je porastao - može se reći duplo, $\mathrm{u}$ odnosu na početak posmatranog perioda. Međutim, različite su bile startne osnove - 2001. ukupan javni dug u Kini je iznosio 24,38\% BDP, a procene IMF-a za 2017. iznose 47,61\% BDP. U SAD, u 2001, javni dug je iznosio 53,022\% BDP-a, dok je već od 2012, on preko $100 \%$ BDP i procene za 2017. iznose 108,14\% BDP (naravno, u ovom dugu Kina ima značajan udeo).
Dakle, potvrđuje se prethodno navedena činjenica da je Kina trenutno jedan od najvećih svetskih investitora i kreditora SAD. S druge strane, SAD u posmatranom periodu konstantno više troše nego što proizvode što se ogleda $u$ deficitu tekućeg računa (Slika 6) i neto međunarodnoj investicionoj poziciji (Slika 7). Iako je deficit tekućeg računa posle svetske finansijske i ekonomske krize smanjen, i iznosi oko 2,5\% BDP-a, 2005. i 2006, deficit je iznosio preko 5\% BDP-a, tako da se moglo postaviti pitanje njegove održivosti. Naročito, 


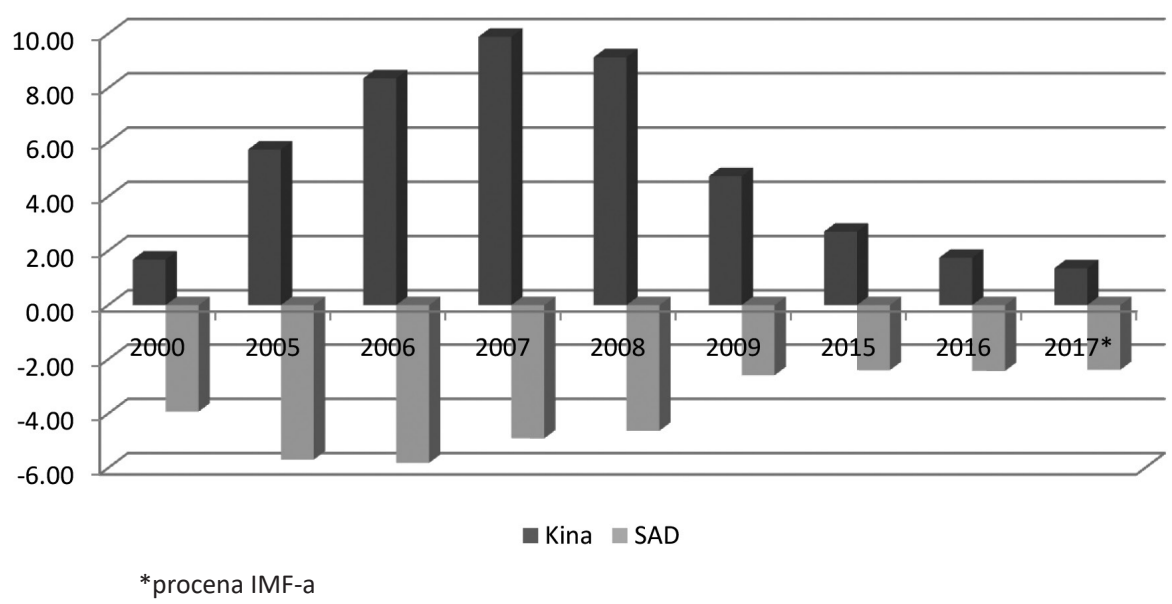

Slika 6 Bilans tekućeg računa, \% BDP-a

Izvor: International Monetary Fund, 2017

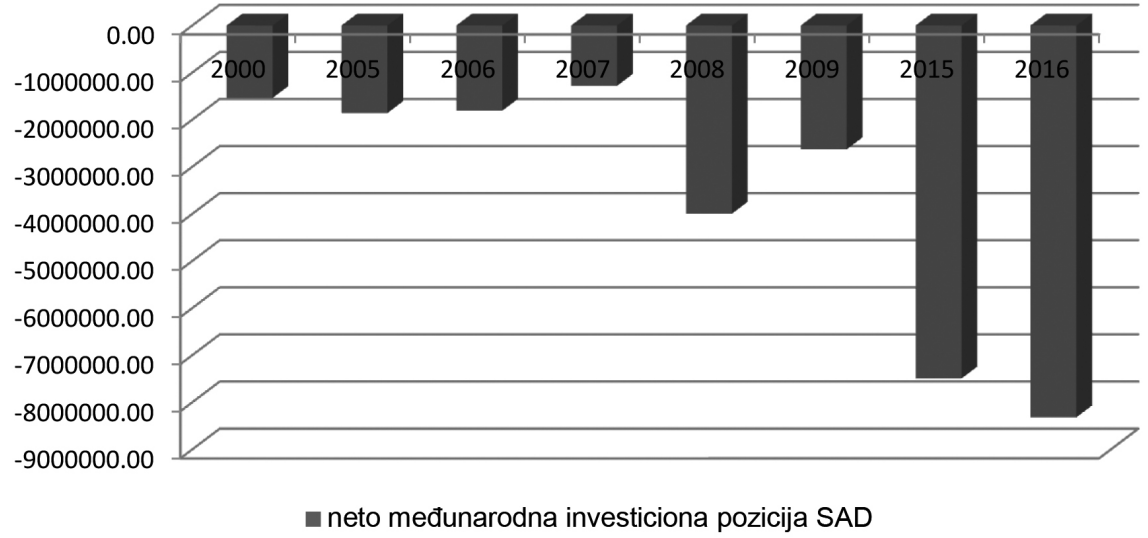

Slika 7 Neto međunarodna investiciona pozicija SAD, milioni dolara

Izvor: Bureau of Economic Analysis, 2018

kada se pogleda apsolutni iznos tog deficita, u pomenutim godinama, on je iznosio oko 800 milijardi dolara. Ovaj podatak još više dobija na značaju kada se $\mathrm{u}$ analizu uključi neto međunarodna investiciona pozicija SAD. SAD su iz pozicije međunarodnog neto poverioca (1980. je neto međunarodna investiciona pozicija iznosila maksimalnih 296,8 milijardi dolara), 1989. prešle u poziciju međunarodnog neto dužnika (33,7 milijardi dolara). Od tada dug SAD manje/više konstantno raste, da bi u 2016. dostigao maksimalnih
8.318,4 milijarde dolara. Ono što je dobro, obzirom na veličinu ekonomije SAD, to je da u relativnom smislu to još uvek nije toliko veliki iznos

\section{POTENCIJAL EVRA}

Zajednička evropska valuta (evro), uvedena od strane 11 zemalja (trenutno ih ima 19), je od strane njenih kreatora (a i šire ekonomske javnosti) bila viđena kao 
valuta koja treba da zaustavi, i smanji dominaciju dolara kao svetske valute. Evro je zauzeo svoje mesto na međunarodnom tržištu i nakon dolara predstavlja najznačajniju valutu. Međutim, nakon svih ovih kriznih godina, postalo je očigledno da je evro uveden pre nego što su se za to stekli svi neophodni uslovi. Njegovi kreatori su verovatno i prilikom uvođenja evra bili svesni da je tadašnje rešenje polovično i nepotpuno. Odnosno, da mora doći do veće ekonomske i političke integracije zemalja evro zone ili će doći do njenog raspada.

Uvođenje evra nije trebalo da bude cilj sam po sebi, nego sredstvo za ostvarivanje većih ciljeva. Smatralo se da će uvođenje zajedničke valute ubrzati ekonomsku integraciju i na dobar način pripremiti teren za dublju političku integraciju, a umesto toga došlo je do suprotnih efekata - stope rasta nisu na zadovoljavajućem nivou, podele su i dalje prisutne. Ukoliko se uzme BDP per capita kao jedan od osnovnih pokazatelja ekonomskog napretka jedne zemlje (ili u ovom slučaju grupacije zemalja), što se evrozone tiče dolazi se do poražavajućih podataka - od 2007-2015. u evrozoni je zabeležen pad realnog BDP per capita za $1,8 \%$ (istovremeno u SAD je zabeležen rast od preko $3 \%$, iako je svetska finansijska i ekonomska kriza nastala u SAD) (Štiglic, 2016).

Pored toga, iako su nove zemlje članice beležile veće stope rasta od starih zemalja, niska startna osnova je bila veliki problem tako da i dalje postoji podela na ,jezgro“ i „periferiju“, „zapad“ i „istok“, odnosno, "sever" i ,jug". Pored ekonomskih nejednakosti i problema koje takva situacija stvara, javljaju se neslaganja i po drugim, veoma važnim pitanjima koja otežavaju funkcionisanje EU, a naročito EMU.

Trenutno (početak 2018.), može se reći da veliki pritisak stvaraju problemi koji se tiču nezavisnosti Katalonije, izlaska Velike Britanije iz EU i priliva migranata. Velika svetska finansijska kriza je otkrila određene slabosti EMU i nakon toga, evro je više godina kao svetska valuta gubio na značaju. Tek 2016. godine, zabeležen je oporavak i evro beleži porast učešća u ukupnim svetskim deviznim rezervama (prema konstantnom deviznom kursu, nakon 6 godina smanjivanja učešća, sa 22,3\% u 2009, na 19,7\% u 2016, zabeleženo je povećanje u odnosu na 2015, na $19,4 \%$ ) i globalnim plaćanjima (sa 29,4\% učešća u 2015, na $31,3 \%$ u 2016.) (ECB, 2017).

Da bi evro nastavio da jača svoju ulogu $u$ međunarodnom monetarnom sistemu, neophodno je prevazići probleme državnih dugova perifernih zemalja članica, sprovoditi reforme, pre svega, u fiskalnoj oblasti i stvoriti dovoljno pouzdanu aktivu (evro obveznicu) koja će moći da parira dubini američkog finansijskog tržišta. Investitori i dalje imaju veliko poverenje $u$ državne obveznice SAD-a i zbog njihove visoke likvidnosti i sigurnosti, praktično ih poistovećuju sa novcem kao najlikvidnijom aktivom (Kovačević, 2011). Zbog svega navedenog, Dž. Štiglic (2016) smatra da je, da bi evrozona uopšte opstala, a kasnije i u još većoj meri ugrozila poziciju dolara, neophodno izvršiti strukturne reforme same evrozone: uspostaviti bankarsku uniju, objediniti dug, stvoriti zajednički okvir za stabilnost, voditi pravu politiku konvergencije, koja će omogućiti strukturno prestrojavanje, promovisati punu zaposlenost i rast za čitavu Evropu i imati potpunu posvećenost zajedničkom prosperitetu. Saglasnost oko bankarske unije je postignuta - pored zajedničkog nadzora, neophodno je imati i zajedničko osiguranje depozita i zajedničko rešavanje problema (iste procedure kada su u pitanju banke koje ne mogu da ispune svoje obaveze).

Međutim, ključno je to da zajednički regulatorni sistem bude postavljen na pravi način - da ne deluje kao automatski destabilizator, već da uz određena (veća) ovlašćenja i adekvatne instrumente podstiče ekspanziju (ograničava kreditiranje) tamo gde je to potrebno. Objedinjavanju duga, takođe, treba pristupiti oprezno. Svakako da bilo koji oblik uspešne ekonomske integracije podrazumeva neku vrstu pomoći koju jače zemlje pružaju slabijim (toga jače zemlje članice moraju biti svesne).

Pri tome, važno je na pravi način koristiti taj objedinjeni dug - ograničiti ga ukoliko je potrebno, trošiti ga na ulaganje isključivo $\mathrm{u}$ određene delove privrede (infrastruktura i obrazovanje na primer), za svako prekomerno zaduživanje ispoštovati propisanu proceduru. Ispunjavanje mastrihtskih 
kriterijuma se pokazalo nedovoljnim da bi se održala stabilnost evrozone u celini, tako da zajednički okvir za stabilnost podrazumeva delovanje u sledećim pravcima: temeljna reforma mastrihtskih kriterijuma konvergencije (pre svega, kroz stvaranje zajedničkog fiskalnog okvira), kolektivno delovanje za rešavanje osnovnih problema kroz Fond solidarnosti za stabilizaciju, posvećenost progresivnim automatskim stabilizatorima, povećanje fleksibilnosti monetarne politike, uvođenje propisa za kontrolu tržišno generisane nestabilnosti i vođenje stabilizujuće fiskalne politike.

Prava politika konvergencije podrazumeva donošenje određenih mera koje će obeshrabrivati zemlje da održavaju suficit tekućih računa. Postizanje ravnoteže tekućeg računa za region $u$ celini nije dovoljno dobro. Pojedinačno gledano, to može da znači da ima zemalja i sa suficitom i sa deficitom, što vremenom može dovesti do problema (pre svega, po pitanju finansiranja deficita) tako da cilj treba da bude sprečavanje prevelikih neravnoteža unutar evrozone.

Puna zaposlenost i kontinuirani rast predstavljaju veliki problem za evrozonu. Kao ključna makroekonomska reforma koja bi trebalo da omogući rešavanje ovog problema izdvaja se promena ovlašćenja ECB. Umesto da bude samo fokusirana na inflaciju, ECB treba svojim širim ovlašćenjima da omogući finansijskom sektoru da posluje u pravcu kreditiranja, pre svega, produktivnih delova privrede, čime će podsticati punu zaposlenost, rast i stabilnost. Posvećenost zajedničkom prosperitetu podrazumeva da je potrebno raditi na otklanjanju problema rastuće nejednakosti koji je prisutan svuda u svetu. Činjenica je da ekonomski, pravni i politički okvir evrozone ne omogućavaju ublažavanje ovog problema. Odnosno, slobodan protok robe i kapitala, bez poreske harmonizacije, upravo pojačava ovaj problem (Štiglic, 2016).

\section{INTERNACIONALIZACIJA JUANA}

Rastuća uloga Azije u svetskoj privredi (pre svega pozicija Kine - najveći svetski izvoznik i dinamičan rast kineske privrede) doprinela je povećanju internacionalizacije juana i pokušaju smanjenja uticaja dolara. Kao što je bilo pokušaja 80-ih i 90 -ih godina $X X$-og veka da se internacionalizuje jen, smatra se da je u XXI-om veku Kina preuzela određene korake koji vode postepenoj internacionalizaciji juana. Narodna banka Kine potpunu konvertibilnost juana vidi kao proces koji se sastoji od tri koraka:

- Juan kao globalna trgovinska valuta - kako se juan bude razvijao kao trgovinska valuta, kompanije van Kine će se sve više navikavati da ga koriste za plaćanje roba i usluga.

- Juan kao globalna investiciona valuta - cilj je da se dozvoli slobodnije investiranje juana. Investitori će biti sposobni da njihove rezerve $\mathrm{u}$ juanima koriste preko granice. Globalne kompanije žele da njihova zarada ostvarena u Kini može biti konvertibilna u druge valute.

- Juan kao globalna rezervna valuta - vlada želi da status njene valute odgovara poziciji zemlje koja postaje ekonomski lider.

Na neki način, Kina želi da ospori dolar kao rezervnu valutu (Love \& Chen, 2017). Iako je potpuna internacionalizacija juana, verovatno, još uvek daleko (može se postaviti pitanje da li to Kina baš sada želi i koliko vremena treba da se to ostvari), svakako da ono što je učinjeno menja situaciju na međunarodnoj sceni. Rastuća uloga juana se ogleda, pre svega, $\mathrm{u}$ tome što izvoznici mogu da robu koju prodaju fakturišu u juanima, postepeno se otvaraju vrata za priliv stranog kapitala (juan se koristi za obračun investicija preko ofšor zona), sa centralnim bankama glavnih trgovinskih partnera otvaraju se bilateralni svop aranžmani u juanima, čime se omogućava obračun i plaćanje u juanima u međusobnoj trgovini i širi se krug valuta za koje se juan direktno razmenjuje bez posredništva dolara (Kovačević, 2014).

Tokom 2016. i 2017, desile su se dve veoma bitne stvari koje idu u prilog internacionalizaciji juana - Međunarodni monetarni fond je uključio juan u korpu valuta kojom se određuje vrednost specijalnih prava vučenja i Evropska centralna banka, kao 
jedna od najmoćnijih centralnih banaka na svetu, je investirala određeni deo svojih deviznih rezervi u juan, prodajući mali deo dolarskih potraživanja. To je deo strategije ECB kojom želi da izvrši diversifikaciju svojih deviznih rezervi i u njih doda i kinesku valutu. Mada je investicija predstavljala svega oko $1 \%$ od njihovih ukupnih deviznih rezervi (oko 68 milijardi evra), a dolar i dalje čini većinu deviznih rezervi ove institucije, bila je veliki podsticaj za Kinu.

Ukazuje se na rastuće poverenje na tržištu za juan, kao svetsku rezervnu valutu i prihvatanje Kine kao globalne ekonomske sile u Evropi. Iz tog razloga, juan je prihvaćen od strane sve više i više zemalja kao rezervna valuta. Međutim, to još uvek ne znači da će juan postati dominantna rezervna valuta umesto dolara (pa i evra) u bliskoj budućnosti (Slika 8). Kao obračunsko sredstvo koristi se za oko $2 \%$ međunarodnih plaćanja, iako je udeo kineskog BDP u svetskom, u poslednjih nekoliko godina, dosta veći i iznosi preko $17 \%$. Iako je najveći trgovac na svetu, Kina izražava svega $20 \%$ svoje spoljne trgovine $u$ juanima, što je mnogo manje od oko $60 \%$ spoljne trgovine evrozone koja je izražena u evrima, ili oko $40 \%$ spoljne trgovine Japana koja je izražena u jenima (Huang, 2017).

Smatra se da je međunarodna uloga juana još uvek ograničena, u poređenju sa dolarom i evrom. Dalja internacionalizacija juana zavisiće od toga da li će Kina uspeti da preusmeri privredu od investicija prema potrošnji, kako bi izbegla zamku srednjeg dohotka. Pri tome, još uvek prisutna ograničenja u računu kapitala umanjuju privlačnost juana za strane investitore (Kovačević, 2015).

Puna konvertibilnost juana, odnosno, da bude $\mathrm{u}$ pravoj meri rezervna valuta, zahteva dalji rad $u$ sledećim oblastima: održavanje ekonomske stabilnosti u smislu stabilnog ekonomskog rasta, stabilnog kursa i niske stope inflacije. Kina povećava udeo u svetskoj trgovini i povećanje veličine njene nacionalne ekonomije je važno njenim trgovinskim partnerima, čime jasno opravdavaju veće korišćenje juana; produbljivanje tržišta kapitala i ubrzavanje integracije sopstvenih i offshore tržišta kapitala; pojačavanje napora u pravcu stvaranja solidnog i pouzdanog, pravnog i regulatornog okvira. Internacionalizacija juana je odlučan cilj nacionalne politike kineske vlade, koji se odigrava bržim tempom nego što se očekivalo. U narednom periodu treba očekivati poboljšanu infrastrukturu u oblasti industrije, pojačane finansijske propise, dobro strukturirane šeme osiguranja depozita, poboljšane tržišno vođene mehanizme izlaska za finansijske institucije itd (Huang, 2017).

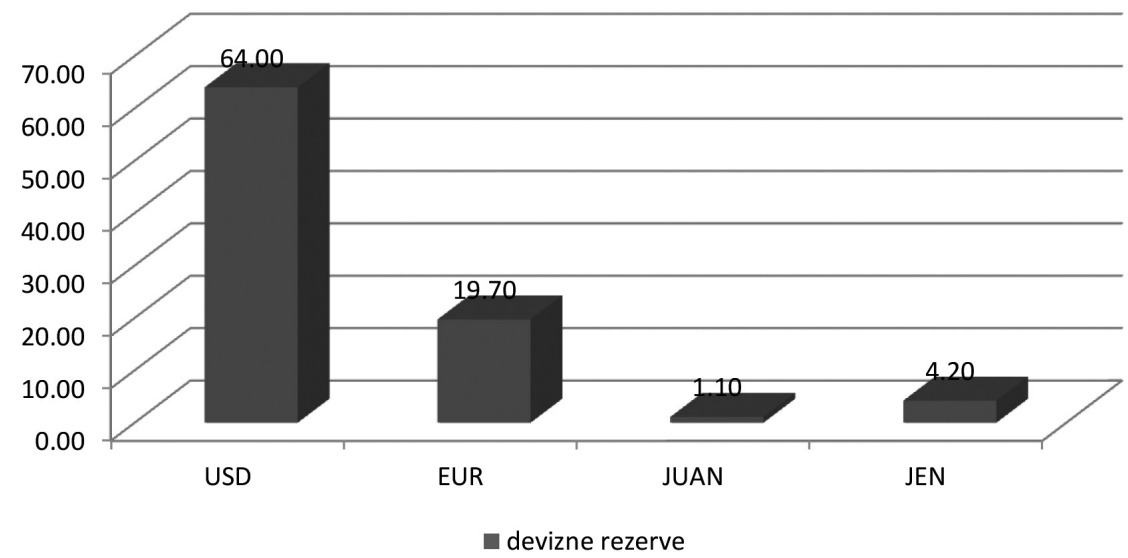

Slika 8 Procentualno učešće najznačajnijih valuta u svetskim deviznim rezervama, 2016. 


\section{UTICAJ GLOBALIZACIJE NA MEĐUNARODNI MONETARNI SISTEM}

Globalizacija je tokom proteklih pola veka imala značajan (pre svega, pozitivan) uticaj na živote ljudi. Problem predstavlja to što dobici koji proizilaze nisu ravnomerno raspoređeni ni na regionalnom, ni na nacionalnom nivou. Vremenom, povećanje međunarodne trgovine i finansijske otvorenosti se dešavalo uporedo. $S$ jedne strane, finansijske veze $u$ vidu međunarodnih plaćanja i kredita su, u velikoj meri, olakšale trgovinu, dok je, istovremeno, došlo do akumulacije međunarodne aktive i obaveza. Sve ovo je uticalo da zemlje koje su trgovinski otvorenije, postanu i finansijski više otvorene. Odnos između realne i finansijske otvorenosti razvijao se stepenom integracije i razvoja. U tom kontekstu, do sada se može govoriti o tri faze globalizacije. Prva, najosnovnija faza podrazumevala je trgovinu robom i gotovim proizvodima i odgovarajuće jednostavne međunarodne finansijske veze, kao što su prekogranična plaćanja. Druga faza obuhvatala je složeniju trgovinu i finansijske veze. Uključivala je trgovinu repromaterijalima i uslugama, povezanu fragmentacijom proizvodnje između zemalja koja je vođena efikasnošću, i uz to odgovarajuće finansijske aranžmane. Treća faza se ticala sve većeg korišćenja finansijskih transakcija kako bi se aktivno upravljalo bilansnim pozicijama. Sve tri faze globalizacije dele neke zajedničke elemente. Jedan od njih je upotreba svetske valute.

Kao dominantna svetska valuta, dolar se koristi za denominaciju, ne samo oko polovine svetske trgovine, već i za oko polovine globalnih prekograničnih bankarskih potraživanja i preko $60 \%$ devizne aktive centralnih banaka i u preko $90 \%$ transakcija na deviznom tržištu. Zahvaljujući tome, dolar i dalje igra ključnu ulogu u određivanju globalnih finansijskih uslova. Drugi zajednički element su globalno aktivne finansijske institucije. One funkcionišu $u$ mnogim zemljama, na više kontinenata. Zahvaljujući međunarodnom prisustvu i soficistiranosti, one olakšavaju prenos sredstava i finansijskih rizika na globalnom nivou. Bilansi kojima se upravlja na konsolidovanom nivou kreiraju bliske međunarodne finansijske veze (Bank for International Settlements,
2017). Veliki problem predstavlja sve veća odvojenost realnog od finansijskog sektora, značajno veći promet koji se ostvaruje na finansijskim tržištima i nedovoljno dobra regulativa na globalnom nivou. $S$ jedne strane, novi finansijski instrumenti i značajne finansijske transakcije omogućavaju lakše finansiranje, ali, s druge strane, na taj način dolazi i do bržeg prenošenja problema između pojedinih delova tržišta.

Pored navedenih promena do kojih je došlo na međunarodnom finansijskom tržištu, prema podacima iz 2016, dolar je i dalje najznačajnija svetska valuta (Slika 9). Evro, kao jedinstvena evropska valuta, iako je uspeo da se pozicionira na drugo mesto, još uvek nije stvorio neki veliki sinergijski efekat i zaostatak u odnosu na dolar je i dalje preveliki. S druge strane, što se azijskog bloka tiče, primetno je da ne postoji jedinstvo (jen je i dalje prisutan), internacionalizacija juana je tek skorije započela i za neko značajnije učešće kineskog juana potrebno je da prođe vreme.

\section{ZAKLJUČAK}

Globalizacija, prisutna u svim segmentima društva, u velikoj meri utiče na značajna prelivanja efekata monetarne politike između zemalja. Iz tog razloga, jačanje međunarodne saradnje, kao i povremene zajedničke akcije monetarnih vlasti su postale neminovnost. Ostaje važno pitanje kako će se u narednom periodu razvijati međunarodni monetarni sistem. Da li će evro i juan uspeti da prošire svoj uticaj? Da li će to biti održiv proces i da li će se to desiti tako što će biti smanjen uticaj dolara? Pored toga, neki novi instrumenti, kao što su virtuelne valute (pre svega, bitkoin), mogu, takođe, predstavljati jedan vid izazova u narednom periodu.

Trenutno, može se reći da dolar još uvek ima dve velike prednosti kada je u pitanju zadržavanje centralne uloge $u$ međunarodnom monetarnom sistemu (čak iako se smatra da je kineska ekonomija postala veća od američke). Prva prednost je to što se postojanje jednog dominantnog međunarodnog novca smatra prirodnim monopolom, i što bi 


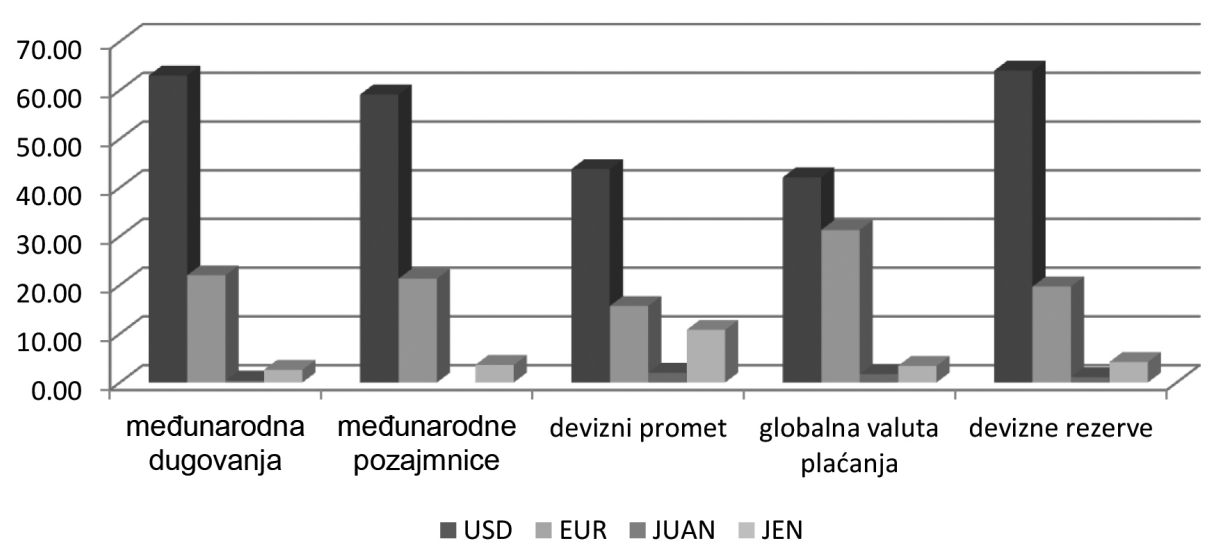

Slika 9 Procentualno učešće najznačajnijih valuta u međunarodnom monetarnom sistemu, 2016.

Izvor: $\mathrm{ECB}, 2017$

uvođenje druge ili treće rezervne valute podiglo administrativne troškove obavljanja međunarodnih plaćanja između različitih zemalja širom sveta. Drugo, postoji velika prednost za nacionalnu valutu koja već ima status međunarodne valute. Kada se privatne transakcije odigravaju tako da većina banaka koristi dolar kao posredničku valutu u razmeni neke druge i treće valute, na ovim tržištima transakcioni troškovi padaju i njihova likvidnost raste. Sa ovakvim padom troškova, i preostale banke su privučene da koriste dolar (McKinnon, 2013).

Što se Evrope tiče, da bi dalje (i što brže) napredovala, mora delovati kolektivno. Cilj je da EU kao celina bude veća od zbira svojih delova (pojedinačnih zemalja) u ekonomskom, socijalnom, tehnološkom, komercijalnom i političkom smislu. Evro kao zajednička valuta, odnosno EMU, mogu biti veoma značajni na tom putu. Međutim, da bi se to desilo, neophodne su ozbiljne ekonomske i političke reforme.

Kineski juan, očigledno, povećava svoj međunarodni uticaj, naročito među zemljama BRIKS-a). Međutim, još uvek se tu ne može govoriti o nekom azijskom bloku koji je vezan za juan. Ipak, neka vrsta tranzicije međunarodnog monetarnog sistema od bipolarnog (američki dolar i evro) ka tripolarnom valutnom bloku (uključen je i juan) je očigledno u toku.
Pored činjenice da se od početka funkcionisanja bretonvudskog međunarodnog monetarnog sistema mnogo toga promenilo i da se konstantno prigovara zbog značajnih beneficija koje SAD imaju zbog ključne uloge dolara u međunarodnom monetarnom sistemu i svetskoj likvidnosti, zaključuje se da pozicija dolara kao najznačajnije svetske valute još uvek nije ugrožena, čime se potvrđuje postavljena hipoteza. Likvidnost, pouzdanost i dubina američkog finansijskog tržišta i dalje u prvi plan stavljaju američke državne hartije od vrednosti. Iako zemlje u razvoju i zemlje u tranziciji povećavaju iznose deviznih rezervi (kao odgovor na sve učestalije krize i sve brže prenošenje tih kriza), i imaju želju da izvrše valutnu diversifikaciju svoje aktive, prethodno navedene činjenice omogućavaju da dolar i dalje zadrži poziciju dominantne valute svetskih deviznih rezervi (Kovačević, 2014). Iako je deficit tekućeg računa SAD veliki i postoji tzv. „fabrička greška" kada je dolar u pitanju (imati poverenja $u$ valutu zemlje koja ima ogroman deficit tekućeg računa), može se zaključiti da pozicija dolara, ipak, ne zavisi toliko od pomenutog deficita, koliko od činjenice da ni jedna druga valuta još uvek ne uspeva značajnije da poveća svoje učešće na međunarodnom finansijskom tržištu. 


\section{ZAHVALNICA}

Ovaj rad je deo Projekta integralnih i interdisciplinarnih istraživanja (broj III 47005), koji finansira Ministarstvo prosvete, nauke i tehnološkog razvoja Republike Srbije

\section{REFERENCE}

Adams, C., \& Park, D. (2009). Causes and consenquences of global imbalances: Perspective from developing Asia. Asian Development Bank Economics, Working Paper Series No. 157. doi.org/10.2139/ssrn.1611424

Bank for International Settlements. (2017). 87 th Annual Report. Basel, Bank for International Settlements.

Blanchard, O., Giavazzi, F., \& Sa, F. (2005). International investitors, the U.S. current account, and the dollar. Global Current Account Imbalances and Exchange Rate Adjustments. Brookings Papers on Economic Activity No 1, pp. $1-49$.

Bureau of Economic Analysis. (2018). Retrieved March 3, 2018, from https://www.bea.gov/international/bp_web/tb_ download_type_modern.cfm?list=2\&RowID=144

European Central Bank (ECB). (2017). The international role of the Euro. Retrieved March 5, 2018, from https://www. ecb.europa.eu/pub/pdf/other/ecb.euro-internationalrole-201707.pdf

Farhi, E., Gournchas, P-O., \& Rey, H. (2011). Reforming the international monetary system. London, UK: Centre for Economic Policy Research.

Filipović, S. i Garić, D. (2014). Analiza uzroka globalne platnobilansne neravnoteže. Poslowna ekonomija, 8(2), 277300. doi:10.5937/PosEko1402277F

Goldberg, L. (2010). Is the international role of the dollar changing? Current Issues in Economics and Finance, 16(1), 1-7.

Goldberg, L. (2011). The international role of the dollar: Does it matter if this changes? Staff Report No. 522. doi.org/10.2139/ ssrn.1945339
Huang, Y. (2017). The growing role of RMB in global reserve currency system. Retrieved January 12, 2018, from http:// www.atimes.com/growing-role-rmb-global-reservecurrency-system/

International Monetary Fund. (2017). World Economic Outlook Database.

Jovanović Gavrilović, P. (2012). Međunarodno poslowno finansiranje. Beograd, Republika Srbija: Ekonomski fakultet Univerziteta u Beogradu.

Kovačević, R. (2011). Reforma međunarodnog monetarnog sistema. Bankarstvo, 9-10, 26-51.

Kovačević, R. (2014). Dolar kao svetska rezervna valuta izazovi i perspective. Bankarstvo, 6, 16-43.

Kovačević, R. (2015). Karakteristike i savremeni izazovi međunarodnog monetarnog i finansijskog sistema. Bankarstvo, 4, 18-39.

Krugman, P. (1984). The international role of the dollar: Theory and prospect. In J, Bilson, \& R. Marston (Eds.). Exchange Rate Theory and Practice (pp. 261-278). Chicago, USA: University of Chicago Press.

Love, H., \& Chen, C. (2017). Chinese renminbi internalization - Guide to recent developments. International Services Chinese Renminbi Internationalization. Retrieved February 8, 2018, from https://www.pnc.com/content/dam/pnc-ideas/ articles/CIB-TM-China-Whitepaper-Update.pdf

McKinnon, R. (2013). The Unloved Dollar Standard. New York, NY: Oxford University Press.

Obstfeld, M., \& Rogoff, K. (2005). Global current account imbalances and exchange rate adjustments. Brookings Papers on Economic Activity, 36(1), 67-123.

Tovar, C., \& Nor, T. (2018). Reserve currency blocks: A changing international monetary system? Working Paper No. 18/20, International Monetary Fund.

Triffin, R. (1978). Gold and the dollar crisis: Yesterday and tomorrow. Princeton, N.J: Princeton University.

Štiglic, Dž. (2016). Evro - kako zajednička valuta ugrožava budućnost Evrope. Novi Sad, Republika Srbija: Akademska knjiga. 
Primljeno 16. marta 2018, nakon revizije, prihvaćeno za publikovanje 23. aprila 2018. Elektronska verzija objavljena 26. aprila 2018.

Nenad Janković je docent Ekonomskog fakulteta Univerziteta u Kragujevcu. Izvodi nastavu na nastavnom predmetu Međunarodne finansije. Doktorat je stekao na Ekonomskom fakultetu Univerziteta u Kragujevcu. Oblasti njegovog naučnog interesovanja su međunarodna ekonomija, međunarodne finansije i politika deviznog kursa.

\title{
PERSPECTIVES OF THE INTERNATIONAL MONETARY SYSTEM
}

\author{
Nenad Jankovic \\ Faculty of Economics, University of Kragujevac, Kragujevac, The Republic of Serbia
}

During the 20th century, the dollar gained the status of the world's most important currency. Therefore, the Bretton Woods International Monetary System was based on the dollar. However, in the 1970s, the situation changed significantly - demand for dollars declined, the currencies of the most important European countries became convertible, the volume of international trade increased greatly, international capital flows were liberalized, the external convertibility of the dollar to gold was abolished, and the currencies began to fluctuate. In this way, the original Bretton Woods international monetary system ceased to exist. In addition to the changes, the functioning of the international monetary system is greatly impacted by the fact that the United States recorded an increasing amount of current account deficits from year to year and, in the 1980s, moved from the position of the net creditor to that of the net debtor, that the euro was created on the soil of the EU and that China became the world's largest exporter and one of the largest (if not the largest) world economies. For this reason, the theoretical assumptions of the international monetary system are systematized in the paper, the role of other world currencies is examined, and the question of why the dollar continues to be the dominant world currency is answered.

Keywords: Bretton Woods International Monetary System, dollar, euro, yuan, world currency

JEL Classification: F31, F32, F33, F62, F65 